This is the version of the article accepted for publication in Journal of International Management published by Elsevier: https://www.journals.elsevier.com/journal-of-international-management/

Accepted version downloaded from SOAS Research Online: http://eprints.soas.ac.uk/30009

Published under: https://creativecommons.org/licenses/by-nc-nd/3.0/

\title{
Outbound Foreign Direct Investment (FDI) Motivation and Domestic Employment by Multinational Enterprises (MNEs) ${ }^{*}$
}

November 24, 2018

\author{
Eunsuk Hong \\ School of Finance and Management \\ SOAS University of London \\ Thornhaugh Street, Russell Square, London WC1H 0XG \\ Tel: (44) 2078984564 \\ Fax: (44) 2078984089 \\ E-mail: e.hong@soas.ac.uk \\ In Hyeock (Ian) Lee** \\ Department of Management \\ Quinlan School of Business, Loyola University Chicago \\ 16 E. Pearson St., Chicago, IL 60611 \\ Tel: (312) 915-7656 \\ Fax: (312) 915-6988 \\ E-mail: ilee1@luc.edu \\ Shige Makino \\ Department of Management \\ The Chinese University of Hong Kong \\ Shatin, N.T., Hong Kong \\ Tel: (852) 3943-7636 \\ Fax: (852) 2603-5104 \\ E-mail: makino@baf.msmail.cuhk.edu.hk
}

\footnotetext{
* This work is equally contributed by authors, who are alphabetically ordered.

${ }^{* *}$ Corresponding author
} 


\title{
Outbound Foreign Direct Investment (FDI) Motivation and Domestic Employment by Multinational Enterprises (MNEs)
}

\begin{abstract}
This study investigates whether and how outbound foreign direct investment (FDI) boosts or reduces domestic employment by multinational enterprises (MNEs). Based on analyses of a firm-level sample of 18,252 subsidiary-year cases of Japanese MNEs in 59 countries from 1996 to 2010, the findings indicate that outbound FDI motivated by (1) market seeking for scale and scope expansion, (2) natural resource seeking, or (3) strategic asset seeking tends to serve as a “strategic complement" that enhances domestic employment by MNEs. However, outbound FDI motivated by (4) market seeking associated with declines in domestic demand or (5) labor resource seeking tends to act as a "strategic substitute" that reduces domestic employment by MNEs. The implications for theory, practice, and policymaking are discussed.
\end{abstract}

Keywords: Outbound FDI, domestic employment, strategic substitute, strategic complement, FDI motivations, Japanese MNEs 


\section{Outbound Foreign Direct Investment (FDI) Motivation and Domestic Employment by Multinational Enterprises (MNEs)}

\section{Introduction}

Scholars have long debated the relationship between outbound foreign direct investment (FDI) by multinational enterprises (MNEs) and the MNEs' employment of domestic personnel. Yet despite five decades of debate, the empirical results remain inconclusive (Lipsey \& Weiss, 1981; Head \& Ries, 2004). Some studies find that outbound FDI and domestic employment are substitutable and have a negative relationship (e.g., Yeaple, 2003; Becker et al., 2005; Kokko, 2006). Other studies find a complementary, positive relation between outbound FDI and domestic employment (e.g., Hijzen, Inui, \& Todo, 2007; Becker \& Muendler, 2008; Federico \& Minerva, 2008; Desai, Foley, \& Hines, 2009). In addition, numerous studies report mixed results that are conditional on firm, country, or industry variations (e.g., Mariotti, Mutinelli, \& Piscitello, 2003; Head \& Ries, 2004; Chen \& Ku, 2005; Harrison \& McMillan, 2007; Konigs \& Murphy, 2006; Ekholm, Forslid, \& Markusen, 2007; Debaere, Lee, \& Lee, 2010; Mitra \& Ranjan, 2010; Hijzen, Jean, \& Mayer, 2011; Driffield, Pereira, \& Temouri, 2017).

These inconsistent findings suggest an interaction between two opposite effects that outbound FDI can have on domestic employment levels. On the one hand, an MNE's outbound FDI may replace its domestic employees with new employees hired by their foreign affiliates (Mariotti, Mutinelli, \& Piscitello, 2003; Greenaway \& Kneller, 2007; Federico \& Minerva, 2008). This kind of replacement typically happens when MNEs engage in a "vertical FDI," especially a labor-seeking FDI into a developing country. In this kind of FDI, the labor-intensive aspects of an MNE's domestic production are transferred to foreign subsidiaries (Blomström, Fors, \& 
Lipsey, 1997; Fors \& Kokko, 2001), resulting in reductions of the MNE's domestic employees. On the other hand, an MNE's outbound FDI may generate more domestic employment due to expanded operations (Lipsey, 1994). This outcome typically happens when MNEs engage in a "horizontal FDI," especially a market-seeking FDI, into an established foreign market where the MNE expands its production base and global market access into developed countries. As horizontal FDI requires an MNE to boost its initial input for the expanded operations (Helpman, Melitz, \& Yeaple, 2004; Greenaway \& Kneller, 2007), this initiative results in an increase of long-term outputs. Therefore, horizontal FDI can increase subsequent domestic employment to satisfy both the increased output demand (Ekholm, Forslid, \& Markusen, 2007; Hijzen, Jean, \& Mayer, 2011) and the increased demand for skilled headquarters services (such as management, financial, legal, R\&D, and marketing) to support the foreign subsidiary operations (Fors \& Kokko, 2001; Mitra \& Ranjan, 2010). In essence, the literature on international economics shares a general consensus that a vertical FDI tends to reduce domestic employment, whereas a horizontal FDI tends to increase domestic employment.

One critical unresolved issue in current discussions on the relationship between outbound FDI and domestic employment is that the literature is preliminarily based on country-level aggregate data, and these data have not effectively addressed the impact of firm heterogeneity. Although the importance of firm heterogeneity has recently been recognized in the literature on international economics (Helpman, Melitz, \& Yeaple, 2004; Bernard, Redding, \& Schott, 2007), many researchers have only just begun to examine the ways that firm heterogeneity can affect the flow of FDI and its outcomes. Also, the literature on international business has traditionally regarded FDI from a strategic management point of view, in which firms are assumed to possess heterogeneous resources, capabilities, and motivations to engage in FDI. However, this literature 
has not yet provided clear insights into under which conditions MNEs can enhance societal welfare, such as domestic employment, through FDI.

In this study, we argue that firm heterogeneity can provide additional explanatory power regarding the impact of outbound FDI on domestic employment beyond the conventional “vertical-horizontal” FDI dichotomy. Specifically, we argue that MNEs have specific strategic motivations for FDI, determined through searching for optimal configurations of firm-specific advantages (FSAs) and country-specific advantages (CSAs). These motivations, which include market seeking, labor resource seeking, natural resource seeking, and strategic asset seeking, integrate FSA configurations (exploitation vs. exploration) with CSA configurations (home vs. host countries) to guide outbound FDI effects. Therefore, the goal of this study is to provide a more nuanced set of predictions regarding the effects of outbound FDI on domestic employment from the perspective of firm heterogeneity. As such, we attempt to answer the following key research questions. (1) Do MNEs' heterogeneous motivations for launching outbound FDI (resulting in the establishment of foreign subsidiaries) directly affect their levels of domestic employment? (2) Which motivations for FDI strategically complement or substitute for an MNE's domestic employment as the firm develops parent-subsidiary relationships? We apply the basic concepts of strategic "complements" vs. "substitutes" to indicate a potential interrelatedness between two strategic decisions by competing firms. If a strategic decision by Firm A enhances (or discourages) the same component of Firm B's strategy, then these two firms' decisions are called strategic complements (or strategic substitutes, respectively) (Bulow, Geanakoplos, \& Klemperer, 1985). Applying these concepts to our research setting, we argue that an outbound FDI motivation and a related domestic employment decision are strategic complements (or substitutes) for each other if the specific outbound FDI motivation for 
establishing foreign subsidiaries increases (or decreases) domestic employment by the parent MNE.

These research questions arise from theoretical observations regarding two distinct but interrelated strategic decisions that MNEs face regarding their international investments. First, MNEs make outbound FDI decisions that involve self-selecting behavior, triggered by specific motivations for outbound FDI projects. Second, the MNEs make simultaneous decisions regarding their (human) resource allocations between parent MNE and foreign subsidiary employment. The initial decision to engage in outbound FDI is critical for an MNE, because this decision determines whether the firm will maintain a shallow integration with foreign markets through exports alone or become deeply integrated into foreign contexts through launching direct investment projects. Therefore, we consider the initial motivation for investment as the main reason for direct foreign entry, as this motivation has the strongest impact on the headquarterssubsidiary structure of an MNE, including its human resource allocations between home and foreign operations. To reflect this theoretical decision structure in our empirical setting, we construct a simultaneous equation model (SEM) with a system of two equations (i.e., one equation for parent MNE employment, and the other for subsidiary employment). Then we estimate the resulting system using three-stage least squares (3SLS) regressions, with the FDI motivation as a key independent decision variable.

We tackle our research questions using a comprehensive dataset on the FDI of Japanese MNEs with established overseas subsidiaries. We use Japanese MNEs and their subsidiaries for two reasons. First, Japan has suffered from severe economic downturns over the past decade, which have caused great debates over whether outbound FDI by Japanese MNEs affects the home economy positively or negatively (Kambayashi \& Kiyota, 2015). Due to the urgent 
relevance of this issue in the Japanese context, a series of both conceptual and empirical studies has been conducted, yielding mixed findings (e.g., Branstetter, 2006; Lipsey, Ramstetter, \& Blomström, 2000; Todo, 2011). This ambiguity has led to calls for more fine-grained studies based on larger samples. A second reason to focus on Japanese MNEs is that the Toyo Keizai dataset now provides the best available information on Japanese MNEs and their subsidiaries. This dataset contains a wide range of subsidiary-level information on Japanese MNEs, including the purposes for overseas establishments and other basic financial indices. The comprehensiveness and accuracy of this dataset has been acknowledged in previous empirical studies (e.g., Beamish, Delios, \& Makino, 2001). Through the extensive use of these firm-level FDI data, we can better understand the strategic relationships between outbound FDI motivations and MNE home-country employment, which is a pressing question in the international business (IB) community. ${ }^{1}$

This study unfolds as follows. In the next section, we propose a conceptual framework with hypotheses to be tested. Next, we discuss our empirical research design in detail. Then we present our empirical results to test the proposed hypotheses. We conclude with discussions of our findings; the theoretical, managerial, and policy implications; and the limitations of this study in relation to future research.

\section{Conceptual framework and hypotheses}

Insert Figure 1 about here

\footnotetext{
${ }^{1}$ Although the Japanese FDI dataset is comprehensive, it does not yet provide information on the compositions or changes of diverse employment groups (e.g., managerial vs. blue-collar jobs) hired by Japanese MNEs in their headquarters and subsidiaries. This limitation confines the main criteria of this study to the total counts of employees hired by Japanese MNEs.
} 
In developing our hypotheses, we use Dunning's (1998) FDI motives as our overarching themes regarding the FSAs (firm-specific advantages) and CSAs (country-specific advantages) of MNEs (Rugman, 1981, 2005; Rugman \& Verbeke, 2001, 2004a), as illustrated in Figure 1. Also, we connect each of Dunning's (1998) FDI motives to the various combinations between FSAs and CSAs. The horizontal axis in Figure 1 indicates whether the MNEs are motivated to exploit or to explore firm-specific assets for conducting outbound FDI (Makino, Lau, \& Yeh, 2002). The firms may be motivated to simply transfer their already-existing internationally transferrable FSAs to foreign subsidiaries in host countries (i.e., FSA replication), or they may attempt to expand/develop their current FSAs to conduct better business in host countries during the course of FSA transfers (i.e., FSA upgrading). Otherwise, they may be motivated to seek opportunities for creating new location-bound FSAs in host countries through entrepreneurial foreign subsidiaries (i.e., new FSA creation).

The vertical axis of Figure 1 represents the two main kinds of motivation MNEs have for seeking CSAs from their host countries (i.e., host CSAs), namely to either complement their current home CSAs or to substitute for them. When MNEs are motivated to seek host CSAs to complement their current home CSAs, they use their home CSAs (e.g., pools of increasing domestic customer bases, access to natural resources, or availability of knowledge/technological resources in their home country) as platforms to further explore additional host CSAs (e.g., expanded customers/markets, foreign endowments of scarce natural resources, or knowledge clusters/sophisticated local firms in their host countries) from expanding their business operations abroad. When MNEs are motivated to seek host CSAs to substitute for their home CSAs, they aim to cultivate new sets of country-specific resources from foreign countries they have difficulty securing within their home country (e.g., a new pool of foreign 
customers/markets, access to cheaper and better labor forces, or the generation of new scientific/marketing knowledge in their host countries). In such situations, MNEs commonly move their domestic functional operations to host countries, and substitute new host CSAs for their declining home CSAs.

\subsection{Market seeking as expansion}

With market-seeking FDI for the purpose of expansion (i.e., Cell I of Figure 1), the aim is to replicate an MNE's internationally transferrable FSAs in foreign markets and expand its business by leveraging new access to foreign customer bases (i.e., additional host CSAs) to complement the firm's current domestic customers (i.e., current home CSAs). Such efforts commonly result in increased domestic employment by MNEs, through either increased production volumes (i.e., scale expansion) or increased ranges of products and services (i.e., scope expansion). Ghemawat (2003) highlights the importance of FSA replication, whereby MNEs exploit market similarities across multiple foreign countries, leading to economies of scale and increased scope of common activities. MNEs that perform this kind of FDI basically replicate their existing FSAs in foreign markets to serve additional foreign customers that MNEs pioneer using their expanded foreign operations. Exploitation of such replicated advantages helps the MNEs to become more competitive in the world market and to generate additional demand for their final outputs (Lipsey, 1994). As such, expansions of both scale and scope require greater coordination and control over geographically dispersed activities. These kinds of expansion require the extension of functions such as R\&D, marketing, and planning, which are typically centralized at the HQ level (Blomström, Fors, \& Lipsey, 1997; Mariotti, Mutinelli, \& Piscitello, 2003). Consequently, the MNEs need to hire more employees at home to support the expanded market opportunities 
gained through these extended functions. In such cases, outbound FDI and domestic employment levels can strategically complement each other.

Hypothesis 1: An MNE's outbound FDI, when motivated by market seeking to enable expansions of market scale or scope, will positively affect the MNE's domestic employment levels.

\subsection{Market seeking as replacement}

In other situations, MNEs may need to explore new market opportunities in foreign countries to compensate for declines in domestic demand. In such situations, an MNE's process of transfer, exploitation, and/or replication of its FSAs may be subject to home country-specific domestic circumstances (Buckley et al., 2007; Lu, Liu, \& Wang, 2011), such as domestic industry life cycles. According to industry life-cycle theory, domestic demand in a new industry typically begins at the introduction stage, and as domestic markets for the new industry mature, they may increase rapidly at the growth stage, after which they eventually decline (Klepper \& Graddy, 1990; Jovanovic \& MacDonald, 1994; Klepper, 1997). When an MNE's industrial sectors reach the last stages of the industry life-cycle in their home country, the firm may have to cultivate new customers in foreign countries to compensate for the decline in domestic customers.

Market-seeking FDI associated with declining domestic demand (i.e., Cell IV of Figure 1) is typically aimed to replicate an MNE's internationally transferrable FSAs in foreign markets. This effort involves finding new foreign customers (i.e., new host CSAs) to substitute for the MNE's declining domestic markets (i.e., current home CSAs). This type of initiative often results in decreased domestic employment by MNEs, because the replacement of declining domestic markets with new foreign markets is commonly accompanied by the restructuring transfer of the MNE's production processes from the home to the host countries. This 
phenomenon is especially prevalent when a traditional fixed-market assumption is imposed on an MNE's foreign operations (Lipsey, 1994). According to this assumption, an MNE's outbound FDI does not expand its efficient production frontiers outward, and given the decline of domestic markets, the MNE needs to secure new foreign customers to replace the declining numbers of domestic customers if it is to remain competitive and profitable. This argument implies that outbound FDI and domestic employment are strategic substitutes for each other under the condition of declining domestic demand. Therefore, when MNEs conduct market-seeking FDI associated with declining domestic demand, home country-specific circumstances may negatively moderate the relationship between market-seeking FDI and domestic employment levels as proposed in the following hypothesis.

Hypothesis 2: An MNE's outbound FDI, when motivated by market seeking to replace domestic customers with foreign customers, will negatively affect the MNE's domestic employment levels under the condition of declining domestic demand.

\subsection{Labor resource seeking}

Labor-resource-seeking FDI (i.e., Cell V of Figure 1) aims to sustain an MNE's internationally transferrable production efficiency by acquiring cheaper and/or better new production factors, such as labor forces in foreign countries (i.e., new host CSAs) to substitute for inefficient domestic labor forces (i.e., current home CSAs). Labor-resource-seeking FDI reduces domestic production as a consequence of relocating the production base to foreign countries, and therefore such investment negatively affects the MNE's domestic employment (Kotabe, 1989). This phenomenon becomes more prominent when the labor-resource-seeking FDI is expedited by export-replacing operations in the host countries, as the export-replacing outbound FDI 
strategically replaces the MNE's indigenous production with outputs produced in host countries (Ekholm, Forslid, \& Markusen, 2007). Such a strategy can also encourage imports back to the MNE's home country, resulting in the further reduction of domestic employees for the MNE. Therefore, when MNEs conduct labor-resource-seeking FDI, the MNE's domestic employment levels may be affected negatively.

Hypothesis 3: An MNE's outbound FDI, when motivated by labor resource seeking, will negatively affect the MNE's domestic employment levels.

\subsection{Natural resource seeking}

Natural-resource-seeking FDI (i.e., Cell II of Figure 1) aims to sustain an MNE's internationally transferrable FSAs in foreign markets by leveraging new access to foreign endowments of scarce natural resources. Such investments serve to create local bases for mining or refining natural resources in foreign countries (i.e., new host CSAs) to complement the MNE's current domestic production factors (i.e., current home CSAs). As natural resources are immobile across countries, MNEs can reduce transaction costs by internalizing scarce natural resources through outbound FDI (Buckley \& Casson, 1976). Also, an MNE's upstream activities (i.e., sourcing of natural resources) are vertically linked to its downstream activities (i.e., production or sales of naturalresource-intensive products), and therefore a greater commitment to natural-resource-seeking FDI leads to greater expansion of business operations in both the MNE's home and host countries. This expansion requires a greater coordination and control over geographically dispersed activities, operating under the vertically integrated value chains of the MNEs. Hence, such natural-resource-seeking FDI may strategically complement an MNE's domestic employment decisions, resulting in increased domestic employment. These arguments lead us to 
suggest that when MNEs conduct natural-resource-seeking FDI in foreign countries, it may positively affect the MNE's domestic employment levels.

Hypothesis 4: An MNE's outbound FDI, when motivated by natural resource seeking, will positively affect the MNE's domestic employment levels.

\subsection{Strategic asset seeking}

Strategic-asset-seeking FDI (i.e., Cells III and VI of Figure 1) aims to create new FSAs through acquiring knowhow and technology that are available in foreign countries, but not in the MNE's home country (i.e., FSA exploration). MNEs can create new FSAs either by complementing their home-based knowledge with that available in their host countries (i.e., Cell III of Figure 1) or by cultivating new knowledge that is unavailable in their home countries (i.e., Cell VI of Figure 1). The first type of FSA exploration involves strategic-asset-seeking FDI by undertaking home base-exploiting R\&D activities (Kuemmerle, 1997). In this type of FDI, MNEs commonly strive to remain responsive to the context of their host country markets through the creation of new location-specific scientific or market-related knowledge as they utilize their home-based knowledge creation as a basis for business development in host countries. The second type of FSA exploration, on the other hand, involves strategic-asset-seeking FDI with the aim to replace weak home-based knowledge with new foreign knowledge generated in host countries. In this type of FDI, MNEs build their foreign R\&D capabilities in host countries to augment their weak home-based innovation and production activities (Kuemmerle, 1997). Both the home-baseexploiting and home-base-augmenting forms of strategic-asset-seeking FDI are likely to result in an increase in domestic employment for MNEs, because parent MNEs need to provide headquarter (HQ) services to their foreign subsidiaries to be combined with knowledge of the 
subsidiaries (Ibarra-Caton \& Mataloni Jr, 2018). In addition, such strategic asset seeking enhances the knowledge creation process across national borders, which typically fuels an MNE's growth through a balanced sequence of knowledge development, use, acquisition, and absorption (Rugman \& Verbeke, 2004b).

In support of these arguments, some studies suggest that strategic-asset-seeking FDI expands an MNE's knowledge base and its opportunities for new business generation (Li et al., 2016; Yoo \& Reimann, 2017; Fu, Hou, \& Liu, 2018), which in turn helps the MNE grow and ultimately increase its domestic employment (Kotabe, 1989; Kotabe \& Swan, 1994). Therefore, when MNEs conduct strategic-asset-seeking FDI in foreign countries, this initiative may positively affect the firms' domestic employment levels.

Hypothesis 5: An MNE's outbound FDI, when motivated by strategic asset seeking, will positively affect the MNE's domestic employment levels.

\section{Research design}

\subsection{Data and sampling}

The primary data sources used in our empirical analyses compile information on the worldwide foreign subsidiaries established by Japanese MNEs. The data on Japanese parent MNEs are drawn from the NIKKEI Economic Electronic Databank System (NEEDS), and are collected by Japan's Ministry of the Economy, Trade, \& Industry (METI). The data on Japanese overseas subsidiaries come from the Toyo Keizai database service. After merging both of these data sources, we exclude all data concerning foreign subsidiaries with (1) two or more parent MNEs or (2) three or more investment purposes. This sampling procedure is followed to avoid potential 
confounding effects. ${ }^{2}$ As we have access to the Toyo Keizai dataset until 2010, but the survey questionnaires for measuring investment purposes are inconsistent until 1995, we confine our study period to 15 years (1996-2010). Our dataset consists of an unbalanced panel with a sample of 3,592 subsidiaries that were established by 799 MNEs operating in 59 countries from 1996 to 2010 , which yields a total of 18,252 subsidiary-year cases. Due to missing values in some variables, 10,094 observations are used for the full sample and 8,712 observations are used for the subsample with majority equity ownership $(\geq 50 \%)$ in foreign subsidiaries. ${ }^{3}$ Both samples are used in our subsequent regression procedure..$^{4}$

\subsection{Dependent variable}

The main dependent variable, the domestic employment by MNEs, is the logged number of domestic employees in a Japanese MNE $p$ at time $t$, denoted as $E M P_{p t}$. The secondary dependent variable, the size of outbound FDI, is the logged number of employees working for an MNE's foreign subsidiary $s$ at time $t$, denoted as $E M P_{s t}$. The secondary dependent variable is needed to address the potential endogeneity of subsidiary employment when estimating the main impact of outbound FDI motivation on the domestic employment by parent MNEs.

\subsection{Hypothesized variables}

\footnotetext{
${ }^{2}$ For example, when there are multiple parent MNEs investing in the same foreign subsidiary, it may not be clear which MNEs' domestic employment levels are affected by a subsidiary investment motivation. In addition, when the same outbound FDI project has multiple motivations, the impacts of motivations that are expected to decrease domestic employment and of motivations that are expected to increase domestic employment by the parent MNEs may generate confounding effects, which are expected to grow more complex as the number of motivations for the same outbound FDI project increases.

${ }^{3}$ There are 1,382 observations with minority ownership ( $\left.<50 \%\right), 2,179$ observations with majority ownership ( $\geq 50 \%$ and $<100 \%)$, and 6,533 observations with full ownership $(=100 \%)$ in the total of 10,094 observations.

${ }^{4}$ As such, so long as multiple subsidiaries are established by MNEs as a part of their initial foreign entries using outbound FDI, those subsidiaries are included separately in our regressions.
} 
The Toyo Keizai database categorizes Japanese FDI into the 15 most commonly observed types of motivations. We construct 15 FDI motivation dummy variables (MD1-MD15) for all subsidiary-year cases, and classify them into six broad motivation categories based on the following theoretical framework: (1) Market-seeking FDI with domestic market expansion, (2) Market-seeking FDI associated with domestic demand decline, (3) Labor-resource-seeking FDI, (4) Natural-resource-seeking FDI, (5) Strategic-asset-seeking FDI (as illustrated in Figure 1), and (6) Other FDI motivations. We use the investment motivations at the time of each firm's initial foreign market entry. ${ }^{5}$ Although we may intuit that the roles of subsidiaries can change over time as they develop, we consider the "initial" investment motivation as the main reason for foreign entry. This initial motivation also typically has the longest-lasting effect on the subsidiaries' operations.

Market-seeking FDI as domestic market expansion. The motivation category of "Market-seeking FDI with domestic market expansion" refers to overseas subsidiaries $s$ of Japanese parent MNEs $p$ at time $t$, when motivated to expand their domestic operations into foreign countries to serve local customers ( $M O T_{\text {Market Expansionpst }}$ ). Four motivation dummies belong to this category. First, "Building international networks of distribution (MD1)" aims to expand distribution networks throughout the world following an expansion of vertical production chain networks. Theoretically, distribution is less fungible than production; although distribution is by definition location-specific, production can be set up anywhere worldwide (Anand \& Delios, 2002). Second, "Market access (MD2)" aims to gain access to host-country local markets by establishing foreign sales subsidiaries (Dunning, 1998). Third, "Export to other countries

\footnotetext{
${ }^{5}$ For those subsidiaries established in 1996 and later, we use the motivation of each subsidiary reported in its establishment year, and, for those subsidiaries established before 1996, we assume that each subsidiary's firstreported motivation in the survey indicates the initial motivation at the time of its establishment.
} 
(MD3)" aims to promote customer-base expansion in third countries beyond an MNE's current home and host country markets (Ekholm, Forslid, \& Markusen, 2007; Hijzen, Jean, \& Mayer, 2011). Fourth, "Controls business of the area (MD4)" aims to establish regional headquarters in response to the creation of integrated regional economic blocks among multiple foreign countries. Such regional headquarters are responsible for the MNEs' foreign operations in the integrated new regional markets, with a particular focus on regional sales and distribution (Buckley et al., 2003; Rugman \& Verbeke, 2004a; Sukpanich \& Rugman, 2007; Verbeke \& Kano, 2016).

Market-seeking FDI with domestic demand decline. The motivation category of "Market-seeking FDI with domestic demand decline" refers to overseas subsidiaries $s$ of Japanese parent MNEs $p$ at time $t$, when motivated to replace their existing domestic operations with foreign operations in association with declining domestic markets $\left(M O T_{\text {Market Replacement,pst }}\right)$. One motivation dummy and four interaction terms belong to this category. First, "Alliance with customers (MD5)" reflects the market-seeking FDI motivation of MNEs whose primary business is to serve their flagship-types of downstream MNE customers in proximity who decided to move into foreign countries (Rugman \& D'Cruz, 2003; Makino, Beamish, \& Zhao, 2004; Narula \& Verbeke, 2015). ${ }^{6}$ Second, four interaction terms between the ratio of Japanese GDP by industry and each of the four motivation variables defined in the "Market-seeking FDI with domestic market expansion" aim to capture market-seeking FDI that is affected by Japanese MNEs' reactions to declining Japanese markets. These variables are (i) MD1. Building international networks of distribution $\times$ Ratio of Japanese GDP by industry, (ii) MD2. Market

\footnotetext{
${ }^{6}$ A good example of this motivation category may be that engine manufacturers must follow their final auto-makers to maintain their current alliance with them who established auto assembly plants in foreign countries. As such, engine manufacturers' outbound FDI in this case is regarded as being motivated by the demand decline in their domestic market, because their direct customers have now moved to foreign countries.
} 
access $\times$ Ratio of Japanese GDP by industry, (iii) MD3. Export to other countries $\times$ Ratio of Japanese GDP by industry, and (iv) MD4. Controls business of the area $\times$ Ratio of Japanese GDP by industry.

Labor-resource-seeking FDI. The motivation category of "Labor-resource-seeking FDI" refers to overseas subsidiaries $s$ of Japanese parent MNEs $p$ at time $t$, when motivated to acquire low-cost labor forces by relocating their domestic production bases to foreign countries ( $\left.M O T_{\text {Labor, pst }}\right)$. Three motivation dummies belong to this category. First, "Labor intensity (MD6)" requires setting up or acquiring subsidiaries in foreign countries with lower real labor costs to replace home-country production of labor-intensive intermediate or final products (Fors \& Kokko, 2001). Second, "Exports to Japan (MD7)" involves replacing domestic production of upward-value activities (e.g., intermediate components) in MNEs' home country with outputs produced in their host countries (Ekholm, Forslid, \& Markusen, 2007). ${ }^{7}$ Third, under the motivation of "Building international networks of production (MD8)," MNEs create value through the transformation of production inputs into demanded outputs across transnational space, which usually replaces some home country production stages (Hennart, 1991).

Natural-resource-seeking FDI. The motivation category of "Natural-resource-seeking FDI" refers to overseas subsidiaries $s$ of Japanese parent MNEs $p$ at time $t$, when motivated to mine and/or refine immobile natural resources available in foreign countries (denoted as $M O T_{\text {NaturalResourcepst }}$ ). The "Natural resources and materials (MD9)" dummy generally involves natural-resource-oriented firms aiming to sustain their FSAs by gaining access to immobile or scarce natural resource endowments in foreign countries (Dunning, 2000).

\footnotetext{
${ }^{7}$ This form of outbound FDI typically takes place when domestic labor forces become too expensive to sustain MNEs' competitive advantages in manufacturing industries. As such, MNEs relocate their production activities to foreign countries in search for low-cost labor forces therein, and they export cost-competitive foreign-manufactured outputs back to Japan from the host countries.
} 
Strategic-asset-seeking FDI. The motivation category of "Strategic-asset-seeking FDI" refers to overseas subsidiaries $s$ of Japanese parent MNEs $p$ at time $t$, when motivated to create new FSAs through either home-base exploiting or home-base augmenting R\&D activities in host countries (denoted as $M O T_{\text {Strategicasset,pst }}$ ). This category has two motivation dummies. The first is "Information gathering, royalty revenue (MD10)," in which MNEs collect information about local markets and technological knowledge in host countries (Knight \& Liesch, 2002) and/or explore local demand for superior innovation capacity in host countries, leading to royalty income (Cohen \& Levinthal, 1990; Rugman \& Verbeke, 2001). Under the second motivation of "R\&D (MD11)," MNEs aim to develop foreign R\&D capabilities by exploring new knowledge, or by identifying highly skilled science and engineering talent in host countries (Cantwell, Dunning, \& Janne, 2004; Lewin, Massini, \& Peeters, 2009; Yoo \& Reimann, 2017).

Other FDI motivations. The motivation category of "Other FDI motivations" refers to subsidiaries $s$ of Japanese parent MNEs $p$ at time $t$, when motivated to achieve various objectives that are not clearly categorized by the conceptual framework in Figure 1 due to their ambiguous effects on domestic employment by MNEs $\left(M O T_{\text {Others,pst }}\right)$. Four motivation dummies belong to this category: (i) "Tax breaks for investments (MD12)," (ii) "Financing and currency hedging (MD13)," (iii) “Trade conflict (MD14)," and (iv) "Building new business (MD15)." As these four motivations are expected to change the opportunity costs for MNEs to conduct businesses in either their home or host countries (thus affecting the domestic employment levels of MNEs), these motivations are included as controls in our subsequent empirical estimations.

\subsection{Control variables}


Our conceptual framework on the relationship among MNEs' FDI motivations, FSAs/CSAs, and their impacts on domestic employment described in Figure 1 implies that domestic employment is determined not only by FDI motivations, but also by firm-specific (i.e., parent \& subsidiary) and country-specific (i.e., home \& host) factors. Hence, in addition to the four motivational controls introduced in the previous subsection, we use eight parent-, subsidiary-, home country-, and host country-specific variables to control for other major determinants of employment and FDI levels that are both theoretically and empirically verified in the previous literature.

In terms of parent firm-specific characteristics, two factors are controlled. First, the size of an MNE's foreign local network is measured by the total number of pre-existing overseas subsidiaries established by each Japanese MNE per host country $h$ in a given year $t\left(N E T_{h t}\right)$. Foreign firms with prior experience in a host country usually have more information about the local environment than first-time entrants, and such foreign experience provides parent MNEs with flexibility in managing their foreign subsidiaries (Makino \& Delios, 1996; Shaver, Mitchell, \& Yeung, 1997; Delios \& Beamish, 2001; Fang et al., 2010). Second, we control for the parent MNE's innovation capacity, calculated by dividing R\&D expenses by operating revenues in the Japanese parent MNE $p$ at time $t\left(R \& D_{p t}\right)$. The parent MNE's subsidiaries are embedded in intra-corporate knowledge networks, and the parent MNE's innovation capacity is one of the important sources of knowledge for its subsidiaries within such networks (Gupta \& Govindarajan, 2000; Delios \& Beamish, 2001; Mudambi \& Navarra, 2004; Fang et al., 2010). In terms of foreign-subsidiary-specific characteristics, we control for each subsidiary’s performance by measuring the logged amount of revenue earned by foreign subsidiary $s$ at time $t\left(S A L E S_{s t}\right)$ (Chan, Isobe, \& Makino, 2008; Fang et al., 2010). 
In terms of home-country-specific characteristics, two factors are assessed. First, the Japanese domestic market structure is measured by calculating the ratio of Japanese GDP by industry $i$ over 22 sectors at time $t\left(I G D P_{i t}\right),{ }^{8}$ as each industry's contributions to Japan's GDP indicate the industrial dynamics of the Japanese economy during our study period (Dekle, 2002). Second, we control for Japan's economic fluctuations during our study period by measuring annual unemployment rates in Japan at time $t\left(U N E M P_{t}\right)$. We consider this factor because the national unemployment rate is widely recognized as an important indicator of economic and business cycles (Martin \& Rogers, 2000).

In terms of host-country-specific characteristics, three factors are set out. First, we control for the market size of each host country by measuring the logged GDP of host country $h$, in which a Japanese MNE invests at time $t\left(G D P_{h t}\right)$. We control for market size because it indicates investment opportunities for MNEs that are looking for new markets or seeking to maximize returns on their investments (Head \& Myer, 2004). Second, the geographic distance between Japan and a Japanese MNE's host economy is measured as the great-circle distance in $\mathrm{km}$ between the capital city of Japan and that of each host country $h$, using longitude and latitude coordinates $\left(D I S_{h}\right)$. Distance can be either an impediment to or an incentive for FDI (Borrmann, Jungnickel, \& Keller, 2005). On the one hand, distance can be an impediment to FDI, as managerial and transaction costs normally increase with distance. On the other hand, distance can be an incentive for FDI, as a means to avoid transportation costs and trade barriers through local production. Third, we use the measure of "rule of law," as applied in the World Bank's

\footnotetext{
${ }^{8}$ The 22 industries are agriculture; forestry and fishing; mining; food products and beverages; textiles; pulp, paper, and paper products; chemicals; petroleum and coal products; non-metallic mineral products; iron and steel; fabricated metal products; machinery; electrical machinery, equipment and supplies; transport equipment; precision instruments; manufacturing, others; construction; electricity, gas, and water supply; wholesale and retail trade; finance and insurance; real estate; transport, and communications; and service activities.
} 
Worldwide Governance Indicators, ${ }^{9}$ as a means to control for heterogeneous legal institutions in host country $h$, in which Japanese MNEs invest at time $t\left(R o L_{h t}\right)$. A host country with wellestablished legal systems and institutions provides a level of stability that makes investors more willing to invest in that country (Globerman \& Shapiro, 2002; Buchanan, Le, \& Rishi, 2012).

We construct the eight control variables with data from the World Economic Outlook Database of the International Monetary Fund for $G D P_{h t}$, from the Japan Statistical Yearbook for $I G D P_{i t}$ and $U N E M P_{t}$, and from the World Bank's Worldwide Governance Indicators for $\operatorname{RoL}_{h t}$.

We use data from the NIKKEI Economic Electronic Databank System for $R \& D_{p t}$, and the Toyo Keizai data for $N E T_{h t}$ and $S A L E S_{s t}$. As we consider Japanese FDI projects across various industries and geographic regions during the 15-year period, we also include industry dummies of Japanese parent MNEs $\left(\alpha_{i}\right)$, regional dummies of host countries $\left(\alpha_{r}\right)^{10}$, and yearly dummies $\left(\alpha_{t}\right)$ in our subsequent estimations.

\subsection{Empirical model and estimation method}

To investigate the relationship between outbound FDI and parent MNE domestic employment with an emphasis on the impact of FDI motivations, we first formulate the following equation:

$$
\begin{aligned}
& E M P_{p t}=\beta_{0}+\beta_{1} M_{\text {MarketExpansion,pst }}+\beta_{2} \text { MOT }_{\text {MarketReplacement,pst }}+ \\
& \beta_{3} M_{\text {Oabor }, p s t}+\beta_{4} \text { MOT }_{\text {NaturalResource,pst }}+\beta_{5} \text { MOT }_{\text {StrategicAsset,pst }}+\beta_{6} \text { MOT }_{\text {Others }, p s t}+ \\
& \beta_{7} E M P_{s t}+\beta_{8} G D P_{h t}+\beta_{9} I G D P_{i t}+\beta_{10} U N E M P_{t}+\beta_{11} D I S_{h}+\beta_{12} R o L_{h t}+\beta_{13} N E T_{h t}+ \\
& \beta_{14} R \& D_{p t}+\alpha_{i}+\alpha_{r}+\alpha_{t}+\epsilon_{p, s, h, i, r, t}
\end{aligned}
$$

\footnotetext{
${ }^{9}$ This indicator has a spread of -2.5 (i.e., low rule of law) to 2.5 (i.e., high rule of law).

${ }^{10}$ Host countries are categorized into seven regional dummies: Asia, Middle East, Europe, North America, Latin America, Africa, and Oceania.
} 
where $\epsilon_{p, s, h, i, r, t}$ is an error term.

Equation (1) has a potential endogeneity issue between the domestic personnel levels of parent MNEs $\left(E M P_{p t}\right)$ and the personnel levels of their foreign subsidiaries $\left(E M P_{s t}\right)$ due to their interdependent connections. MNEs may make "simultaneous" decisions regarding the employment levels for both parent MNEs and foreign subsidiaries when they implement outbound FDI to achieve optimal allocations of human resources across national borders. To deal with this problem in our regressions, we specify the second equation for the determining employment by foreign subsidiaries to obtain an instrumental variable for the endogenous employment levels of foreign subsidiaries:

$$
\begin{aligned}
& E M P_{s t}=\beta_{0}+\beta_{1} M O T_{\text {MarketExpansion,pst }}+\beta_{2} \text { MOT }_{\text {MarketReplacement,pst }}+ \\
& \beta_{3} M_{\text {Oabor,pst }}+\beta_{4} \text { MOT }_{\text {NaturalResource,pst }}+\beta_{5} \text { MOT }_{\text {StrategicAsset,pst }}+\beta_{6} \text { MOT }_{\text {Others }, p s t}+ \\
& \beta_{7} E M P_{p t}+\beta_{8} G D P_{h t}+\beta_{9} I G D P_{i t}+\beta_{10} U N E M P_{t}+\beta_{11} D I S_{h}+\beta_{12} R o L_{h t}+\beta_{13} N E T_{h t}+ \\
& \beta_{14} S A L E S_{s t}+\alpha_{i}+\alpha_{r}+\alpha_{t}+\epsilon_{p, s, h, i, r, t}
\end{aligned}
$$

To cope with the endogeneity of $E M P_{p t}$ and $E M P_{s t}$, we construct a simultaneous equation model (SEM) with a system of equations (1) and (2), and then estimate the system using three-stage least squares (3SLS) regressions, ${ }^{11}$ which combine instrumental variable (IV) techniques and generalized least square (GLS) estimators. The 3SLS achieves consistency through appropriate instrumentation and efficiency through optimal weighting. It also corrects for the correlation between the disturbances across the two equations (Greene, 2008, p. 407).

\footnotetext{
${ }^{11}$ To satisfy the order condition for identification in the 3SLS estimation, we assume that the R\&D capacity of parent MNEs $\left(R \& D_{p t}\right)$ in equation (1) will have a direct impact on domestic employment by parent MNEs, but only an indirect impact on employment by their overseas subsidiaries. Correspondingly, we assume that the sales performance of overseas subsidiaries $\left(S A L E S_{s t}\right)$ in equation (2) will have a direct impact on the employment by overseas subsidiaries, but only an indirect impact on domestic employment by their parent MNEs.
} 


\section{Results}

Insert Tables $1-4$ about here

Tables 1 and 2 provide the descriptive statistics and correlations of the variables we use in our equation system, as introduced in the previous section. Tables 3 and 4 provide our empirical results from the 3SLS regressions using (1) our full sample and (2) those observations with majority equity ownership ( $\geq 50 \%$ ) in foreign subsidiaries, respectively, to test Hypotheses 1-5. The empirical results are reported in three models, step by step, in each table. These models are the control only model (Model 1), the control and motivation dummy model (Model 2), and the control, motivation dummy, and interaction model (Model 3). Japanese overseas subsidiary employment levels (as presented in column 5 of Tables 3 and 4) are shown to positively affect parent MNE employment levels with statistical significance $(\beta=0.538$ at $p=0.0001$ for the full sample, and $\beta=0.558$ at $p=0.0001$ for ownership $\geq 50 \%$ ), indicating that a $1 \%$ increase in the Japanese subsidiary's employment is likely to increase the parent MNE's overall home employment by $0.538 \%$ and $0.558 \%$, respectively, with $99 \%$ confidence. ${ }^{12}$ However, as illustrated in the same column of both tables, when we factor in the different motivations for outbound FDI projects as revealed by Japanese MNEs, this conclusion may be premature or misleading. The direct effects of outbound FDI on Japanese MNEs' domestic employment levels are heavily dependent on the specific motivations for the Japanese MNEs' investments, which are affected by an optimal configuration of FSAs and CSAs for those MNEs.

First, when MNEs expand their business by leveraging new access to foreign customers to complement their current domestic customers (i.e., Market-seeking FDI with domestic market

\footnotetext{
${ }^{12}$ When both the dependent and independent variables are logged variables in an econometric equation, the estimated coefficient represents elasticity between the two variables, with all other variables held constant.
} 
expansion, in Cell I of Figure 1), such outbound FDI projects are shown to increase domestic employment by MNEs in Japan as those firms seek to serve the additional foreign customers gained from their expansion. Outbound FDI that aims to gain direct access to host-country local markets by establishing foreign sales subsidiaries adds extra demand to the MNEs' current exploitation of their home markets (MD2: Market access, $\beta=0.268$ at $p=0.0001$ for the full sample, and $\beta=0.357$ at $p=0.0001$ for ownership $\geq 50 \%$ ). Outbound FDI via the establishment of foreign sales subsidiaries that aim to serve neighboring foreign countries with market potential (MD3: Exports to other countries, $\beta=0.246$ at $p=0.021$ for the full sample, and $\beta=0.561$ at $p=$ 0.0001 for ownership $\geq 50 \%$ ) commonly generates greater demand for MNE outputs. When MNEs establish regional headquarters through outbound FDI to control their foreign businesses in specific areas, their main motive is to boost regional sales in economically integrated blocks (e.g., NAFTA, EU, ASEAN) by becoming insiders (MD4: Controls business in the area, $\beta=$ 0.542 at $p=0.008$ for the full sample, and $\beta=1.154$ at $p<0.0001$ for ownership $\geq 50 \%$ ). These empirical results imply that outbound FDI projects triggered by these three motivations are likely to increase Japanese MNEs' home employment by 19.48\% (MD2: Market access), 0.89\% (MD3: Exports to other countries), and $0.70 \%$ (MD4: Controls business in the area), with either 99\% or $95 \%$ confidence for the full sample when evaluated at the mean value of each motivation. ${ }^{13}$ These effects are enhanced to $26.02 \%, 2.08 \%$, and $1.62 \%$, respectively, with $99 \%$ confidence for the subsample with majority ownership. However, outbound FDI of Japanese MNEs aiming to expand their global distribution networks has no statistically significant effect on their domestic

\footnotetext{
${ }^{13}$ From $\log y=\beta_{0}+\beta_{1} \cdot x+e,\left(\frac{d y}{d x}\right) / y=\beta_{1}$. By multiplying $x$ on both sides and rearranging the resulting equation, it follows that $\left(\frac{d y}{y}\right) /\left(\frac{d x}{x}\right)=\beta_{1} \cdot x$. As $\left(\frac{d x}{x}\right)$ always represents 1 when $x$ is a dummy variable (i.e., $x$ changes from 0 to 1 ), the percentage (\%) change of $y$ can be calculated as $\left(\frac{d y}{y}\right) \cdot 100=\beta_{1} \cdot \bar{x} \cdot 100$ at the mean value of $x$.
} 
employment levels (MD1. Building international networks of distribution, $\beta=0.181$ at $p=0.240$ for the full sample, and $\beta=0.248$ at $p=0.141$ for ownership $\geq 50 \%$ ). All of this evidence partially supports Hypothesis 1 that outbound FDI with a market-seeking motivation due to domestic market expansion is likely to be a strategic complement to domestic employment by MNEs.

Second, when MNEs explore new foreign markets to substitute for declining domestic demand (i.e., Market-seeking FDI with domestic market decline, in Cell IV of Figure 1), such outbound FDI projects are shown to reduce the parent MNE's overall home employment levels. In column 5 of Tables 3 and 4, outbound FDI following downstream customers by forming alliances with them significantly and negatively affects the domestic employment levels of Japanese MNEs (MD5: Alliance with customers in Japan, $\beta=-0.449$ at $p=0.0001$ for the full sample, and $\beta=-0.500$ at $p=0.0001$ for ownership $\geq 50 \%$ ). These findings indicate that such outbound FDI is likely to reduce the parent MNEs' home employment by $0.90 \%$ and $1.05 \%$, respectively, with $99 \%$ confidence when evaluated at the mean value of FDI motivation.

In the same column of both Tables 3 and 4, our regressions include the interaction terms between the ratio of Japanese GDP by industry, and each of MD1, MD2, MD3, and MD4, as the interaction terms presumably show negative and significant signs when outbound FDI projects with market-seeking motivation are conditioned by the MNEs' reactions to declining domestic markets. Indeed, [MD2 $\times$ Ratio of Japanese GDP by industry], [MD3 $\times$ Ratio of Japanese GDP by industry], and [MD4 $\times$ Ratio of Japanese GDP by industry] generate significantly negative coefficients, as shown in column 5 of Tables 3 and $4(\beta=-0.016$ at $p=0.0001, \beta=-0.023$ at $p=$ 0.019 , and $\beta=-0.029$ at $p=0.058$, respectively, for the full sample, and $\beta=-0.023$ at $p=$ $0.0001, \beta=-0.042$ at $p=0.0001$, and $\beta=-0.065$ at $p=0.0001$, respectively, for ownership $\geq$ 
50\%). These results imply that when Japanese MNEs are motivated to conduct market-seeking FDI under the home country-specific disadvantageous circumstances of declining domestic demand, such outbound FDI projects are likely to result in the decrease of the parent MNEs' home employment by $0.15 \%$ (MD2: Market access), $0.21 \%$ (MD3: Exports to other countries), and $0.27 \%$ (MD4: Controls business in the area), with $99 \%, 95 \%$, and $90 \%$ confidence, respectively, for the full sample, as the ratio of their participating industry in the Japanese GDP reduces by $1 \% .{ }^{14}$ For the subsample with majority ownership, these effects become stronger at $0.23 \%, 0.42 \%$, and $0.64 \%$, respectively, with $99 \%$ confidence. Although it is insignificant for the full sample, [MD1 $\times$ Ratio of Japanese GDP by industry] still shows a significantly negative coefficient for the subsample of ownership $\geq 50 \%(\beta=-0.020$ at $p=0.099)$. This result signifies that when Japanese MNEs undertake overseas investment with the motive of building international distribution channels to overcome downturns in their participating domestic industries, a $1 \%$ decrease in the share of the industry (in terms of Japanese GDP) is likely to result in a decrease of the MNE's home employment by $0.20 \%$ with $90 \%$ confidence. In considering all of these results, we conclude that outbound FDI with a market-seeking motivation is likely to become a strategic substitute for domestic employment by MNEs under the disadvantageious condition of declines in domestic demand. These results support Hypothesis 2.

\footnotetext{
${ }^{14}$ From $\log y=\beta_{0}+\beta_{1} \cdot x_{1}+\beta_{2} \cdot x_{2}+\beta_{3} \cdot\left(x_{1} \cdot x_{2}\right)+e$, where $x_{1}$ is a motivational dummy and $x_{2}$ is an industrial composition (\%), $\left(\frac{\partial y}{\partial x_{2}}\right) / y=\beta_{2}+\beta_{3} \cdot x_{1}$. By multiplying $x_{2}$ on both sides and rearranging the resulting equation, it follows that $\left(\frac{\partial y}{y}\right) /\left(\frac{\partial x_{2}}{x_{2}}\right)=\beta_{2} \cdot x_{2}+\beta_{3} \cdot x_{1} \cdot x_{2}$, which indicates an elasticity between $y$ and $x_{2}$, when evaluated at certain values of $x_{1}$ and $x_{2}$. When outbound FDI projects are triggered by a certain motivation (i.e., $x_{1}$ changes from 0 to 1 ), marginal changes in the elasticity can be calculated as $\beta_{3} \cdot \bar{x}_{2}$ at the mean value of $x_{2}$.
} 
Third, when MNEs internationalize to replace their inefficient domestic labor forces with new production factors from foreign countries (i.e., Labor-resource-seeking FDI, in Cell V of Figure 1), such outbound FDI projects are also shown to reduce the parent MNEs' overall home employment levels. In column 5 of Tables 3 and 4, directly relocating the labor-intensive, homebased production base to foreign countries with lower labor costs significantly and negatively affects the domestic employment levels of Japanese MNEs (MD6: Labor Intensity, $\beta=-0.145$ at $p=0.002$ for the full sample, and $\beta=-0.128$ at $p=0.012$ for ownership $\geq 50 \%$ ). We interpret this result as indicating that such outbound FDI is likely to reduce the parent MNEs' home employment by $1.39 \%$ and $1.22 \%$ for each sample with $99 \%$ and $95 \%$ confidence, respectively, when evaluated at the mean value of the motivation. Replacing domestic consumption of upward-value activities in the MNEs' home country with outputs produced in their host countries (MD7: Exports to Japan) and establishing trans-border production networks with foreign manufacturing partners (MD8: Building international networks of production) both generate inconsistent signs of coefficients. However, these results are shown to be statistically insignificant. All of these results partially support Hypothesis 3 that labor-resource-seeking outbound FDI is likely to become a strategic substitute for domestic employment by MNEs.

Fourth, when MNEs establish a local base for mining or refining immobile natural resources that are available in foreign countries as a means to complement their scarce domestic production factors (i.e., Natural-resource-seeking FDI, in Cell II of Figure 1), such outbound FDI projects are shown to increase the parent MNEs' home employment levels. In the case of MNEs operating in natural-resource-intensive industries such as oil, gas, and energy, securing access to such scarce natural resources and materials in host countries is necessary for those MNEs to sustain their unique FSAs. Securing such access results in expanded business opportunities with 
more employees hired at home. The results, shown in column 5 of Table 4, support this view (MD9: Natural resources and materials, $\beta=0.336$ at $p=0.001$ for ownership $\geq 50 \%$ ). These findings indicate that this kind of outbound FDI is likely to enhance the levels of domestic employment by Japanese MNEs by $0.71 \%$ with $99 \%$ confidence, when evaluated at the mean value of the FDI motivation. These results partially support Hypothesis 4, predicting that outbound FDI with a natural-resource-seeking motivation is likely to serve as a strategic complement to domestic employment by MNEs.

Fifth, when MNEs internationalize to create new FSAs, either by complementing their home-based knowledge with that available in host countries or by cultivating new knowledge/ technological resources that are unavailable in their home countries (i.e., Strategic-asset-seeking FDI, in Cells III and VI of Figure 1), such outbound FDI projects are shown to boost MNEs' domestic employment levels. The empirical evidence shown in column 5 of Tables 3 and 4 partially supports the co-evolutionary relationship predicted by Hypothesis 5. Japanese foreign subsidiaries that are motivated to obtain relevant market and/or scientific information indirectly in host countries are shown to significantly and positively affect the home employment levels of Japanese MNEs (MD10: Information gathering, $\beta=0.311$ at $p=0.0001$ for the full sample, and $\beta=0.392$ at $p=0.0001$ for ownership $\geq 50 \%$ ). As a result of such strategic-asset-seeking FDI activities, additional employees are hired at home to serve newly expanded business opportunities abroad. Specifically, these kinds of outbound FDI projects are likely to enhance the parent MNEs' home employment levels by $5.82 \%$ and $7.68 \%$ with $99 \%$ confidence, respectively, for each sample when evaluated at the mean value of the FDI motivation. Although insignificant, conducting direct R\&D (MD11:R\&D) still shows positive coefficients in the same column of both tables. All of these results partially support Hypothesis 5 that outbound FDI with a 
strategic-asset-seeking motivation is likely to serve as a strategic complement to domestic employment by MNEs.

Insert Tables 5 and 6 about here

Table 5 summaries the aforementioned empirical estimation results per each of the five hypotheses put forward in this study. To guarantee the robustness of the empirical findings, we conduct four robustness tests with the sample of majority equity ownership ( $\geq 50 \%$ ) in foreign subsidiaries, as reported in Table 6. First, it is important to see whether incorporating alternative time lags between the outbound FDI motivations and the MNEs' domestic employment levels change our empirical findings. Therefore, we use $(t+1),(t+2)$, and $(t+3)$ lagged variables of the domestic employment levels in our regressions. Second, we use a subsample of the parent MNEs, namely those MNEs that have only one subsidiary for each host country, as a test to confirm that our main empirical results are not sensitive to the numbers of subsidiary networks established by the MNEs. Third, we conduct a robustness test with the subsample of Japanese foreign subsidiaries that have only one FDI motivation. Lastly, we use the system generalized method of moments (GMM) on the parent-firm employment equation (1) as an alternative to the 3SLS empirical model to confirm that our findings are not sensitive to potential endogeneity or autocorrelation issues. ${ }^{15}$ All of the robustness checks show qualitatively similar results to our main findings as reported in Tables 3 and 4.

\footnotetext{
${ }^{15}$ The system GMM is based on two equations, that is, the "level" and "difference" equations, and uses lagged differences and levels as instrumental variables (IVs) to estimate the level and difference equations, respectively. The system GMM estimators need to pass two specification tests for the selected IVs to be statistically valid: (1) Hansen's J test and (2) the difference-in-Hansen test. In addition, the system GMM estimators need to pass AR(1) and $\operatorname{AR}(2)$ serial correlation tests using the first-differenced residuals to indicate that the original error terms are not serially correlated. If the original error terms in the level equation are not serially correlated, the AR(1) test should be significant, whereas the AR(2) test should be insignificant. The far-right column for the system GMM in Table 5 demonstrates that the system GMM estimators passed all of these specification tests.
} 


\section{Discussion and conclusion}

\subsection{Summary of empirical findings}

Using an unbalanced panel with a sample of 3,592 subsidiaries established by 799 MNEs operating in 59 countries from 1996 to 2010 (with a total of 18,252 subsidiary-year cases), we analyze the effects of heterogeneous FDI "motivations" as revealed by the MNEs on the relationships between various types of outbound FDI and the MNEs' domestic employment levels. Overall, our 3SLS estimation results indicate three conclusions. First, outbound FDI projects motivated by (1) market seeking for scale and scope expansion, (2) natural resource seeking, or (3) strategic asset seeking tend to boost domestic employment by MNEs (i.e., strategic complements). Second, outbound FDI projects motivated by (4) market seeking associated with declining domestic demand or (5) labor resource seeking reduce domestic employment by MNEs (i.e., strategic substitutes). Finally, across the range of motivations, outbound FDI motivation tends to have a greater impact on domestic employment when the MNEs have strong resource commitments or control over their subsidiaries in the form of majority ownership.

These empirical findings imply that "motivations" are endogenous to MNEs' strategic decisions about outbound FDI (Makino, Lau \& Yeh, 2002), and, hence, could lead to variations in the FDI outcomes even under similar country-specific conditions. Most mainstream IB studies explore a variety of conditions leading to variations in firm behavior and performance; for example, Michael Porter's national diamond and five forces framework, John Dunning's Ownership-Location-Internalization (OLI) framework of FDI, and Jay Barney’s Valuable-RareInimitable-Nonsubstitutable (VRIN) resources framework. These frameworks, while popular, 
allow little room for researchers to explore different motivations that lead to variations in MNE behavior. As such, the empirical results from this current study highlight the value of examining the motivations of outbound FDI using firm-level data that should complement the conventional FDI research stream that pays limited attention to firm heterogeneity in analyzing the effect of FDI on MNEs' performance/outcomes such as domestic employment.

\subsection{Contribution to the IB literature}

The association between outbound FDI and domestic employment has been discussed in terms of three issues: (i) whether production by the foreign affiliates of MNEs serves as a substitute or a complement to home country production by the parent MNEs (or by other home country firms);

(ii) how FDI activities affect the domestic employment structure and the wage differences in a home country; and (iii) how FDI activities affect the labor intensity of home production (Mariotti, Mutinelli, \& Piscitello, 2003, p. 420). Our study focuses on the first aspect of the FDIemployment relationship by examining whether and how MNEs' motivations for launching outbound FDIs (resulting in the establishment of foreign subsidiaries) increase or decrease their domestic employment levels. Our study makes three main contributions to the previous literature.

First, our study underscores the importance of firm heterogeneity in the determination of domestic employment levels by MNEs, thereby providing insight into an issue that has been relatively neglected in the previous international trade and investment literature. Major studies in international economics (with a primary focus on the horizontal vs. vertical roles of CSAs in trade and FDI) have paid very limited attention to the roles of FSAs in affecting the outbound FDI decisions of MNEs, which may in turn affect their decisions regarding employment at home. Our study integrates MNEs' configuring their FSAs through FDI (i.e., exploitation vs. 
exploration) with the traditional discussions on horizontal vs. vertical FDI for configuring CSAs. Furthermore, our study examines whether and how certain motivations for outbound FDI projects are likely to increase or decrease domestic employment by MNEs. The key thrust of this study is that FDI is a self-selecting behavior, and MNEs possess different motivations for conducting FDI. Among the primary FDI motivations suggested by Dunning (1998), we show that the motivations of market seeking (for scale and scope expansion), natural resource seeking, and strategic asset seeking in host countries all serve to aggregate or create FSAs in foreign markets, thereby leading to stronger "competitive advantages" for MNEs. As a result, outbound FDI projects conducted for these motives are expected to expand foreign markets, resulting in increased domestic employment by MNEs. Conversely, the motivations of market seeking associated with declines in domestic demand and of labor resource seeking aim to exploit the "comparative advantages" of foreign subsidiary nations during the course of FSA arbitrage, so that MNEs can obtain access to growing foreign markets and more efficient foreign labor resources. Therefore, outbound FDI projects implemented under these motivations aim to vertically relocate segments of MNE manufacturing to host countries, thereby, reducing the MNEs' domestic employment.

Second, the integration of heterogeneous FSAs into the traditional CSA configuration helps to disentangle underlying mechanisms in the relationships between certain FDI motivations and domestic employment by MNEs. For example, conventional studies in international economics commonly fail to differentiate between market-seeking FDI for the sake of scale and scope expansion (i.e., Cell I in Figure 1) and market-seeking FDI to substitute for declines in domestic markets (i.e., Cell IV in Figure 1). In addition, conventional studies often fail to consider the different effects that (natural) resource-seeking FDI (i.e., Cell II in Figure 1) and 
strategic-asset-seeking FDI (i.e., Cell III and VI in Figure 1) have on domestic employment by MNEs. By incorporating insights on heterogeneous FSAs from the field of international business studies into the traditional discussions on the horizontal vs. vertical roles of CSAs, our study puts forward a solid conceptual framework that can explain cases not previously investigated in conventional international economics studies.

Third, by expanding the traditional FSAs-CSAs framework through the perspective of MNE heterogeneity, our study provides a solid theoretical foundation on which we can predict MNEs' optimal allocations of scarce human resources across national borders in the form of their decisions regarding domestic employment. As has been highlighted in the recently developed resources/capabilities-based view of MNEs (Pitelis \& Teece, 2010), human resources and capabilities are among the substantial assets that can be easily and successfully scaled by MNEs across national borders. The optimal employment decisions of MNEs are normally focused on their headquarters-subsidiary structures, and these decisions can be effectively leveraged intrafirm between the home and host country branches of MNEs.

\subsection{Contribution to practice and policy}

This study also provides important practical implications for both managers of MNEs and public policymakers, both of whom are concerned with the possible economic and social impacts of reduced domestic employment following the relocation of production bases. As discussed earlier, our study shows that certain types of outbound FDI can have negative effects on domestic employment, especially when the FDI is aimed toward seeking low-cost labor or finding new markets associated with declining home demand. However, our findings also show that the other types of outbound FDI usually have a positive impact on domestic employment. This evidence 
also suggests that even in cases with negative effects, MNEs can reduce the harmful impact on domestic markets by making parallel FDI efforts that enhance domestic employment. Such concurrent approaches may help MNEs maintain their business "legitimacy" among the people of their home countries. MNEs that seek to aggregate or create FSAs using either horizontal or vertical FDIs tend to increase domestic employment to a significant extent, as these investments serve to increase demand from expanded foreign markets. Making such investments is important for not only maintaining domestic employment levels, but also helping domestic firms expand and gain international competitive advantages. These expanding firms can "endogenize" their CSAs and build their own FSAs, thereby increasing their domestic employment.

\subsection{Limitations and future research direction}

This study has several limitations, which suggest directions for future research. First, due to the limited information provided by the Japanese FDI dataset, we examine only total counts of employees, without specifying employment levels (management vs. non-management), worker types (white-collar vs. blue-collar), or status (full-time vs. part-time). This data limitation may generate an aggregating bias in our empirical evidence, as other observations have indicated that outward FDI increases managerial jobs but reduces blue-collar jobs at home. Our generalized information may blur the real substitutional effects between competing groups of employees within MNEs, as it only shows whether total domestic employment declines as a result of the outbound FDI. Furthermore, since the dataset is compiled based on annual survey, there may be missing observations, missing values, and/or entry errors in the data which generate potential bias in statistical analyses. While prior studies have suggested that the data are generally reliable and trustworthy (Isobe, Makino, \& Montgomery, 2000; Delios \& Beamish, 2001), further 
research is needed to verify that such bias does not affect the interpretations of the empirical results. Second, we acknowledge that the motivations for investment in subsidiaries may change over time as the subsidiaries develop. Such changes in motivation can encourage MNEs to consider "relocations" of subsidiaries (Makino \& Tsang, 2011), resulting in subsequent changes in employment among the multiple subsidiaries and headquarters of MNEs. As our study focuses on domestic employment by MNEs that pursue outbound FDI, we do not consider potential changes in employment among foreign subsidiaries after their initial entry that may be affected by the various motivations for outbound FDI. Third, some MNEs may have multiple motivations for direct investment in foreign countries. As such, the net effects that differing motivations for outbound FDI have on the parent MNEs' domestic employment levels may be blurred. Thus, we need more in-depth investigations along this line. Fourth, although we attempt to control for unobserved fixed effects by including industry dummies of Japanese parent MNEs $\left(\alpha_{i}\right)$, regional dummies of their host countries $\left(\alpha_{r}\right)$, and yearly dummies $\left(\alpha_{t}\right)$ in our empirical estimations, we acknowledge that we do not control for all of the factors that may potentially influence the outcome variable in our study. Lastly, our study is based on a sample of MNEs from a single country, Japan. Clearly, our conceptual discussions on the relationship between outbound FDI motivations and domestic employment by MNEs should also be applied and extended to other country contexts. We hope others will join us in this line of research, as it opens a new avenue for rich inquiry regarding MNE strategies, FDI motivations, and the growth of home economies. 


\section{References}

Anand, J., Delios, A., 2002. Absolute and relative resources as determinants of international acquisitions. Strategic Management Journal. 23(2), 119-134.

Beamish, P.W., Delios, A., Makino, S., 2001. Japanese Subsidiaries in the New Global Economy. Edward Elgar, Cheltenham, UK.

Becker, S.O., Ekholm, K., Jäckle, R., Muendler, M.A., 2005. Location choice and employment decisions: A comparison of German and Swedish multinationals. Review of World Economics. 141(4), 693-731.

Becker, S.O., Muendler, M.A., 2008. The effect of FDI on job security. The B.E. Journal of Economic Analysis \& Policy. 8(1), Article 8.

Bernard, A.B., Redding, S.J., Schott, P.K., 2007. Comparative advantage and heterogenous firms. Review of Economic Studies. 74(1), 31-66.

Blomström, M., Fors, G., Lipsey, R.E., 1997. Foreign direct investment and employment: Home country experience in the United States and Sweden. Economic Journal. 107(445), 17871797.

Borrmann, C., Jungnickel, R., Keller, D., 2005. What Gravity Models Can Tell Us About the Position of German FDI in Central and Eastern Europe. HWWA Discussion Paper No. 328. Hamburg Institute of International Economics.

Branstetter, L., 2006. Is foreign direct investment a channel of knowledge spillovers? Evidence from Japan's FDI in the United States. Journal of International economics. 68(2), 325344.

Buchanan, B.G., Le, Q.V., Rishi, M., 2012. Foreign direct investment and institutional quality: Some empirical evidence. International Review of Financial Analysis. 21, 81-89.

Buckley, P., Casson, M., 1976. The Future of the Multinational Enterprise. Holmes and Meier, London.

Buckley, P.J., Clegg, J., Forsans, N., Reilly, K.T., 2003. Evolution of FDI in the United States in the context of trade liberalization and regionalization. Journal of Business Research. 56, 853-857.

Buckley, P.J., Clegg, L.J., Cross, A.R., Liu, X., Voss, H., Zheng, P., 2007. The determinants of Chinese outward foreign direct investment. Journal of International Business Studies. 38, 499-518.

Bulow, J., Geanakoplos, J., Klemperer, P.D., 1985. Multimarket oligopoly: Strategic substitutes and complements. Journal of Political Economy. 93(3), 488-511.

Cantwell, J.A., Dunning, J.H., Janne, O.E.M., 2004. Towards a technology-seeking explanation of U.S. direct investment in the United Kingdom. Journal of International Management. 10, 5-20.

Chan, C.M., Isobe, T., Makino, S., 2008. Which country matters? Institutional development and foreign affiliate performance. Strategic Management Journal. 29(11), 1179-1205. 
Chen, T.-J., Ku, Y.-H., 2005. The effects of overseas investment on domestic employment. In: Ito, T., Rose, A.K. (Eds.), International Trade in East Asia, NBER-East Asia Seminar on Economics, Volume 14. University of Chicago Press, Chicago, pp. 109-127.

Cohen, W.M., Levinthal, D.A., 1990. Absorptive capacity: A new perspective on learning and innovation. Administrative Science Quarterly. 35(1), 128-152.

Debaere, P., Lee, H., Lee, J., 2010. It matters where you go: Outward foreign direct investment and multinational employment growth at home. Journal of Development Economics. 91(2), 301-109.

Dekle, R., 2002. Industrial concentration and regional growth: Evidence from the prefectures. Review of Economics and Statistics. 84(2), 310-315.

Delios, A., Beamish, P.W., 2001. Survival and profitability: The roles of experience and intangible assets in foreign subsidiary performance. Academy of Management Journal. 44(5), 1028-1038.

Desai, M.A., Foley, C.F., Hines Jr., J.R., 2009. Domestic effects of the foreign activities of US multinationals. American Economic Journal: Economic Policy. 1(1), 181-203.

Driffield, N., Pereira, V., Temouri, Y., 2017. Does offshore outsourcing impact home employment? Evidence from service multinationals. Journal of Business Research. http://dx.doi.org/10.1016/j.jbusres.2017.09.051.

Dunning, J.H., 1998. Location and the multinational enterprise: A neglected factor? Journal of International Business Studies. 29(1), 45-66.

Dunning, J.H., 2000. The eclectic paradigm as an envelope for economic and business theories of MNE activity. International Business Review. 9(2), 163-190.

Ekholm, K., Forslid, R., Markusen, J.R., 2007. Export-platform foreign direct investment. Journal of the European Economic Association. 5(4), 776-795.

Fang, Y., Jiang, G.-L.F., Makino, S., Beamish, P.W., 2010. Multinational firm knowledge, use of expatriates, and foreign subsidiary performance. Journal of Management Studies. 47(1), 27-54.

Federico, S., Minerva, G.A., 2008. Outward FDI and local employment growth in Italy. Review of World Economics. 144(2), 295-324.

Fors, G., Kokko, A., 2001. Home-country effects of FDI: Foreign production and structural change in home-country operations. In: Blomström, M., Goldberg, L. (Eds.), Topics in Empirical International Economics: A Festschrift in Honor of E. Lipsey. University of Chicago Press, Chicago, pp. 137-157.

Fu, X., Hou, J., Liu, X., 2018. Unpacking the relationship between outward direct investment and innovation performance: Evidence from Chinese firms. World Development. 102, $111-123$.

Ghemawat, P., 2003. Semiglobalization and international business strategy. Journal of International Business Studies. 34(2), 138-152.

Globerman, S., Shapiro, D., 2002. Global foreign direct investment flows: The role of governance infrastructure. World Development. 30(11), 1899-1919. 
Greenaway, D., Kneller, R., 2007. Firm heterogeneity, exporting and foreign direct investment. The Economic Journal. 117(517), F134-F161.

Greene, W.H., 2008. Econometric Analysis. Prentice-Hall, Upper Saddle River, NJ.

Gupta, A., Govindarajan, V., 2000. Knowledge flows within multinational corporations. Strategic Management Journal. 21(4), 473-496.

Harrison, A.E., McMillan, M.S., 2007. U.S. multinational activity abroad and U.S. jobs: Substitutes or complements? Industrial Relations. 46(2), 347-365.

Head, K., Mayer, T., 2004. Market potential and the location of Japanese investments in the European Union. Review of Economics and Statistics. 86(4), 949-972.

Head, K., Ries, J., 2004. Exporting and FDI as alternative strategies. Oxford Review of Economic Policy. 20(3), 409-423.

Helpman, E., Melitz, M., Yeaple, S., 2004. Export versus FDI with heterogeneous firms. American Economic Review. 94(1), 300-316.

Hennart, J.-F., 1991. The transaction costs theory of joint ventures: An empirical study of Japanese subsidiaries in the United States. Management Science. 37(4), 483-497.

Hijzen, A., Inui, T., Todo, Y., 2007. The effects of multinational production on domestic performance: Evidence from Japanese firms. RIETI Discussion Paper Series, No. 07-E006, Research Institute of Economy, Trade and Industry, Tokyo.

Hijzen, A., Jean, S., Mayer, T., 2011. The effects at home of initiating production abroad: Evidence from matched French firms. Review of World Economics. 147(3), 457-483.

Ibarra-Caton, M., Mataloni Jr, R.J., 2018. Headquarter services in the global integration of production. Journal of International Management. 24, 93-107.

Isobe, H., Makino, S., Montgomery, D.B., 2000. Resource commitment, entry timing, and market performance of foreign direct investments in emerging economies: The case of Japanese international joint ventures in China. Academy of Management Journal. 43(3), 468-484.

Jovanovic, B., MacDonald, G.M., 1994. The life cycle of a competitive industry. Journal of Political Economy. 102(2), 322-347.

Kambayashi, R., Kiyota, K., 2015. Disemployment caused by foreign direct investment? Multinationals and Japanese employment. Review of World Economics. 151, 433-460.

Klepper, S., 1997. Industry life cycles. Industrial and Corporate Change. 6(1), 145-182.

Klepper, S., Graddy, E., 1990. The evolution of new industries and the determinants of market structure. Rand Journal of Economics. 21(Spring), 24-44.

Knight, G.A., Liesch, P.W., 2002. Information internalisation in internatinalising the firm. Journal of Business Research. 55, 981-995.

Kokko, A., 2006. The home country effects of FDI in developed economies. EIJS Working Paper No. 225, European Institute of Japanese Studies, Stockholm.

Konigs, J., Murphy, A., 2006. Do multinational enterprises relocate employment to low-wage regions? Evidence from European multinationals. Review of World Economics. 142(2), 267-286. 
Kotabe, M., 1989. "Hollowing-out" of U.S. multinationals and their global competitiveness: An intrafirm perspective. Journal of Business Research. 19(1), 1-15.

Kotabe, M., Swan, K.S., 1994. Offshore sourcing: Reaction, maturation, and consolidation of U.S. multinationals. Journal of International Business Studies. 25(1), 115-140.

Kuemmerle, W., 1997. Building effective capabilities abroad. Harvard Business Review. MarchApril, 61-70.

Lewin, A.Y., Massini, S., Peeters, C., 2009. Why are companies offshoring innovation? The emerging global race for talent. Journal of International Business Studies. 40(6), 901-925.

Li, J., Strange, R., Ning, L., Sutherland, D., 2016. Outward foreign direct investment and domestic innovation performance: Evidence from China. International Business Review. 25, 1010-1019.

Lipsey, R., 1994. Outward direct investment and the U.S. economy. In: Feldstein, M., Hines, J., Hubbard, R.G. (Eds.), The Effects of Taxation on Multinational Corporations. University of Chicago Press, Chicago, pp. 7-42.

Lipsey, R., Ramstetter, E., Blomström, M., 2000. Outward FDI and parent exports and employment: Japan, the United States, and Sweden. Global Economy Quarterly. 1(4), 285-302.

Lipsey, R., Weiss, M., 1981. Foreign production and exports in manufacturing industries. Review of Economics and Statistics. 63(4), 488-494.

Lu, J., Liu, X., Wang, H., 2011. Motives for Chinese outward FDI: Firm resources, industry dynamics, and government policies. Management and Organization Review. 7(2), 223248.

Makino, S., Beamish, P.W., Zhao, N.B., 2004. The characteristics and performance of Japanese FDI in less developed and developed countries. Journal of World Business. 39(4), 377392.

Makino, S., Delios, A., 1996. Local knowledge transfer and performance: Implications for alliance formation in Asia. Journal of International Business Studies. 27(5), 905-928.

Makino, S., Lau, C.M., Yeh, R.S., 2002. Asset exploitation versus asset seeking: Implications for location choice of foreign direct investment. Journal of International Business Studies. 33(3), 403-421.

Makino, S., Tsang, W.E. 2011. Historical ties and foreign direct investment: An exploratory study. Journal of International Business Studies. 42(4), 545-557.

Mariotti, S., Mutinelli, M., Piscitello, L., 2003. Home country employment and foreign direct investment: Evidence from the Italian case. Cambridge Journal of Economics. 27(3),419431.

Martin, P., Rogers, C., 2000. Long-term growth and short-term economic instability. European Economic Review. 44(2), 359-381.

Mitra, D., Ranjan, P., 2010. Offshoring and unemployment: The role of search frictions labor mobility. Journal of International Economics. 81(2), 219-229. 
Mudambi, R., Navarra, P., 2004. Is knowledge power? Knowledge flows, subsidiary power and rent-seeking within MNCs. Journal of International Business Studies. 35(5), 385-406.

Narula, R., Verbeke, A., 2015. Making internalization theory good for practice: The essence of Alan Rugman's contributions to international business. Journal of World Business. 50(4), 612-622.

Pitelis, C.N., Teece, D.J., 2010. Cross-border market co-creation, dynamic capabilities and the entrepreneurial theory of the multinational enterprise. Industrial and Corporate Change. 19(4), 1247-1270.

Rugman, A.M., 1981. Inside the Multinationals: The Economics of Internal Markets. Columbia University Press, New York.

Rugman, A.M., 2005. The Regional Multinationals. Cambridge University Press, Cambridge.

Rugman, A.M., D’Cruz, J.R., 2003. Multinationals as Flagship Firms: Regional Business Networks. Oxford University Press, Oxford.

Rugman, A.M., Verbeke, A., 2001. Subsidiary-specific advantages in multinational enterprises. Strategic Management Journal. 22(3), 237-250.

Rugman, A.M., Verbeke, A., 2004a. Perspective on regional and global strategies of multinational enterprises. Journal of International Business Studies. 35(1), 3-18.

Rugman, A.M., Verbeke, A., 2004b. A final word on Edith Penrose. Journal of Management Studies. 41(1), 205-217.

Shaver, J.M., Mitchell, W., Yeung, B., 1997. The effect of own-firm and other-firm experience on foreign direct investment survival in the United States, 1987-92. Strategic Management Journal. 18, 811-824.

Sukpanich, N., Rugman, A.M., 2007. Intra-regional sales, product diversity, and the performance of merchandising multinationals. Journal of International Management. 13, 131-146.

Todo, Y., 2011. Quantitative evaluation of the determinants of export and FDI: Firm-level evidence from Japan. The World Economy. 34(3), 355-381.

Verbeke, A., Kano, L., 2016. An internalization theory perspective on the global and regional strategies of multinational enterprises. Journal of World Business. 51(1), 83-92.

Yeaple, S.R., 2003. The role of skill endowments in the structure of U.S. outward foreign direct investment. Review of Economics and Statistics. 85(3), 726-734.

Yoo, D., Reimann, F., 2017. Internationalization of developing country firms into developed countries: The role of host country knowledge-based assets and IPR protection in FDI location choice. Journal of International Management. 23, 242-254. 


\begin{tabular}{|c|c|c|c|}
\hline \multirow{3}{*}{$\begin{array}{c}\text { To } \\
\text { Complement } \\
\text { Home CSA }\end{array}$} & \multicolumn{2}{|c|}{ FSA Exploitation } & \multirow{2}{*}{$\begin{array}{c}\text { FSA Exploration } \\
\text { To Create New FSA }\end{array}$} \\
\hline & To Replicate Existing FSA & To Sustain Existing FSA & \\
\hline & $\begin{array}{l}\text { Cell I: } \\
\text { - } \quad \text { Market-seeking FDI (+) } \\
\text { - Scale expansion } \\
\text { - Scope expansion }\end{array}$ & $\begin{array}{l}\text { Cell II: } \\
\text { - Natural-resource-seeking } \\
\text { FDI (+) } \\
\text { - Access to scarce and } \\
\text { immobile foreign endowment } \\
\text { of natural resources }\end{array}$ & $\begin{array}{l}\text { Cell III: } \\
\\
\text { - Strategic-asset-seeking } \\
\text { FDI (+) } \\
\text { - Home-base-exploiting } \\
\text { R\&D activities }\end{array}$ \\
\hline $\begin{array}{c}\text { To } \\
\text { Substitute } \\
\text { Home CSA }\end{array}$ & $\begin{array}{l}\text { Cell IV: } \\
\text { - Market-seeking FDI (-) } \\
\text { - Associated with } \\
\text { domestic demand decline }\end{array}$ & $\begin{array}{l}\text { Cell V: } \\
\text { Labor-seeking FDI (-) } \\
-\quad \text { Replacement of } \\
\text { inefficient domestic labor } \\
\text { forces }\end{array}$ & $\begin{array}{l}\text { Cell VI: } \\
\text { - } \quad \text { Strategic-asset-seeking } \\
\text { FDI }(+) \\
\text { - Home-base-augmenting } \\
\text { R\&D activities }\end{array}$ \\
\hline
\end{tabular}

* Among the four FDI motives suggested by Dunning (1998), we remove the efficiencyseeking FDI motivation and focus on market-seeking, resource-seeking (natural or labor resources), and strategic-asset-seeking FDI motivations in the conceptual framework. Efficiency seeking can be achieved by combining some or all of the other FDI motivations, which implies the existence of inconclusive confounding effects of the efficiency-seeking FDI motivation on MNEs' domestic employment.

Figure 1. Conceptual framework 
Table 1. Descriptive statistics

\begin{tabular}{|c|c|c|c|c|}
\hline \multirow[b]{2}{*}{ Variables } & \multicolumn{2}{|c|}{ Full sample } & \multicolumn{2}{|c|}{ Ownership $\geq 50 \%$} \\
\hline & Mean & Std. Dev. & Mean & Std. Dev. \\
\hline 1. Japanese parent MNE employment (ln) & 8.495 & 1.396 & 8.477 & 1.406 \\
\hline 2. Overseas subsidiary employment (ln) & 3.831 & 1.699 & 3.710 & 1.665 \\
\hline 3. Host country GDP $(\ln )$ & 27.558 & 1.677 & 27.684 & 1.682 \\
\hline 4. Ratio of Japanese GDP by industry (\%) & 9.387 & 6.464 & 9.882 & 6.370 \\
\hline 5. Unemployment rate in Japan (\%) & 4.604 & 0.518 & 4.603 & 0.517 \\
\hline 6. Distance between Japan and host countries (ln) & 32.905 & 31.987 & 35.540 & 32.596 \\
\hline 7. Host country rule of law & 0.942 & 0.820 & 1.028 & 0.801 \\
\hline 8. Parent MNE local networks (ln) & 0.477 & 0.664 & 0.465 & 0.652 \\
\hline 9. Parent MNE R\&D ratio (\%) & 0.023 & 0.028 & 0.024 & 0.029 \\
\hline 10. Overseas subsidiary revenue $(\ln )$ & 9.380 & 1.988 & 9.377 & 1.991 \\
\hline 11. MD1. Building international networks of distribution & 0.073 & 0.261 & 0.079 & 0.269 \\
\hline 12. MD2. Market access & 0.727 & 0.446 & 0.729 & 0.445 \\
\hline 13. MD3. Exports to other countries & 0.036 & 0.186 & 0.037 & 0.188 \\
\hline 14. MD4. Controls business of the area & 0.013 & 0.113 & 0.014 & 0.117 \\
\hline 15. MD5. Alliance with customers in Japan & 0.020 & 0.140 & 0.021 & 0.142 \\
\hline 16. MD6. Labor intensity & 0.096 & 0.295 & 0.095 & 0.293 \\
\hline 17. MD7. Exports to Japan & 0.018 & 0.133 & 0.019 & 0.137 \\
\hline 18. MD8. Building international networks of production & 0.180 & 0.384 & 0.165 & 0.371 \\
\hline 19. MD9. Natural resources, materials & 0.021 & 0.144 & 0.021 & 0.143 \\
\hline 20. MD10. Information gathering, royalty revenue & 0.187 & 0.390 & 0.196 & 0.397 \\
\hline 21. MD11. R\&D & 0.028 & 0.164 & 0.030 & 0.170 \\
\hline 22. MD12. Tax breaks for investment & 0.033 & 0.180 & 0.029 & 0.169 \\
\hline 23. MD13. Financing, currency hedging & 0.011 & 0.105 & 0.012 & 0.108 \\
\hline 24. MD14. Trade conflict & 0.011 & 0.103 & 0.012 & 0.110 \\
\hline 25. MD15. Building new business & 0.015 & 0.121 & 0.016 & 0.124 \\
\hline
\end{tabular}

Notes. a. $N=10,094$ for the full sample, and 8,712 for the subsample of Japanese MNEs with majority equity ownership ( $\geq 50 \%)$ in foreign subsidiaries. 
Table 2. Correlation matrix for full sample

\begin{tabular}{|c|c|c|c|c|c|c|c|c|c|c|c|c|c|c|c|c|c|c|c|c|c|c|c|c|}
\hline & 1 & 2 & 3 & 4 & 5 & 6 & 7 & 8 & 9 & 10 & 11 & 12 & 13 & 14 & 15 & 16 & 17 & 18 & 19 & 20 & 21 & 22 & 23 & 24 \\
\hline 1 & 1.00 & & & & & & & & & & & & & & & & & & & & & & & \\
\hline 2 & $0.33^{* * *}$ & 1.00 & & & & & & & & & & & & & & & & & & & & & & \\
\hline 3 & $-0.11^{* * *}$ & $-0.07 * * *$ & 1.00 & & & & & & & & & & & & & & & & & & & & & \\
\hline 4 & $-0.03^{* * *}$ & $-0.46^{* * * *}$ & $0.12^{* * *}$ & 1.00 & & & & & & & & & & & & & & & & & & & & \\
\hline 5 & 0.01 & -0.01 & $-0.06^{* * *}$ & -0.01 & 1.00 & & & & & & & & & & & & & & & & & & & \\
\hline 6 & -0.001 & $-0.18^{* * * *}$ & $0.67 * * a$ & $0.23^{* * *}$ & -0.001 & 1.00 & & & & & & & & & & & & & & & & & & \\
\hline 7 & 0.003 & $-0.36^{* * *}$ & $0.22^{* * *}$ & $0.35^{* * * *}$ & 0.01 & $0.60^{* * *}$ & 1.00 & & & & & & & & & & & & & & & & & \\
\hline 8 & $0.37^{* * *}$ & $0.19^{* * *}$ & $0.24 * * *$ & $-0.12^{* * *}$ & -0.01 & 0.01 & $-0.18 * * *$ & 1.00 & & & & & & & & & & & & & & & & \\
\hline 9 & $-0.03^{* * *}$ & $-0.04 * * *$ & $0.12^{* * * *}$ & $0.10^{* * *}$ & $0.06 * * *$ & $0.09 * * *$ & $0.07 * * *$ & $-0.02^{*}$ & 1.00 & & & & & & & & & & & & & & & \\
\hline 10 & $0.40^{* * *}$ & $0.54 * * *$ & $0.08^{* * *}$ & $-0.08^{* * * *}$ & $-0.02^{* *}$ & $0.15^{* * *}$ & $0.18^{* * *}$ & $0.12^{* * *}$ & $0.04 * * *$ & 1.00 & & & & & & & & & & & & & & \\
\hline 11 & $-0.12^{* * *}$ & $-0.17^{* * * *}$ & -0.01 & $0.17^{* * *}$ & -0.01 & $-0.02^{* *}$ & 0.01 & $-0.08 * * *$ & -0.004 & $-0.06 * * *$ & 1.00 & & & & & & & & & & & & & \\
\hline 12 & $-0.03 * *$ & $-0.09 * * *$ & $0.08 * * *$ & $0.16 * * *$ & 0.004 & $0.08 * * *$ & $0.13^{* * *}$ & $-0.11^{* * * *}$ & 0.02 & $0.06 * * *$ & $-0.13^{* * *}$ & 1.00 & & & & & & & & & & & & \\
\hline 13 & 0.01 & 0.02 & $-0.10^{* * * *}$ & $-0.03^{* * *}$ & 0.004 & $-0.08^{* * * *}$ & -0.005 & 0.004 & -0.01 & $0.02 * *$ & 0.003 & $-0.08^{* * *}$ & 1.00 & & & & & & & & & & & \\
\hline 14 & 0.02 & $-0.07 * * *$ & $-0.02^{*}$ & $0.03^{* * *}$ & 0.01 & $0.02^{*}$ & $0.07 * * *$ & $0.02^{* *}$ & $0.02^{* *}$ & 0.005 & -0.005 & $-0.03^{* * *}$ & $-0.02^{*}$ & 1.00 & & & & & & & & & & \\
\hline 15 & $-0.05 * * *$ & $0.03^{* * *}$ & 0.01 & $-0.06^{* * *}$ & 0.01 & -0.001 & $-0.02^{* *}$ & 0.01 & $0.02^{* *}$ & $-0.02^{* *}$ & $-0.03^{* * *}$ & $-0.07 * * *$ & $-0.03^{* * *}$ & $-0.02^{*}$ & 1.00 & & & & & & & & & \\
\hline 16 & $0.06^{* * *}$ & $0.26^{* * * *}$ & $-0.18^{* * *}$ & $-0.21^{* * *}$ & -0.004 & $-0.24 * * *$ & $-0.26^{* * * *}$ & $0.06^{* * *}$ & $0.02 * *$ & $0.03^{* * *}$ & $-0.09 * * *$ & $-0.21^{* * * *}$ & $0.06^{* * *}$ & $-0.03 * * *$ & $-0.04 * * *$ & 1.00 & & & & & & & & \\
\hline 17 & 0.01 & $0.07 * * *$ & $-0.03^{* * *}$ & $-0.08^{* * *}$ & 0.01 & $-0.07 * * *$ & $-0.13^{* * * *}$ & $0.08^{* * *}$ & $-0.02^{* * *}$ & $-0.04 * * *$ & $-0.04 * * *$ & $-0.13^{* * * *}$ & -0.01 & -0.02 & $-0.02^{*}$ & $0.08^{* * *}$ & 1.00 & & & & & & & \\
\hline 18 & $0.02^{* * *}$ & $0.22^{* * *}$ & $-0.05 * * *$ & $-0.43^{* * *}$ & -0.0002 & $-0.17 * * *$ & $-0.30^{* * *}$ & $0.11^{* * *}$ & $-0.06^{* * *}$ & 0.01 & $-0.07 * * *$ & $-0.28^{* * *}$ & $-0.05 * * *$ & $-0.05 * * *$ & $-0.03^{* * *}$ & $-0.05 * * *$ & $0.02^{* *}$ & 1.00 & & & & & & \\
\hline 19 & 0.01 & $-0.06^{* * *}$ & $-0.03 * * *$ & $-0.07 * * *$ & 0.01 & $-0.02^{* *}$ & $0.03 * * *$ & 0.01 & 0.01 & 0.01 & $-0.03 * * *$ & $-0.18^{* * * *}$ & $-0.03 * * *$ & $-0.02^{*}$ & $-0.02^{* *}$ & 0.01 & 0.001 & -0.01 & 1.00 & & & & & \\
\hline 20 & 0.01 & $-0.24^{* * *}$ & $0.12^{* * *}$ & $0.30^{* * *}$ & -0.001 & $0.20^{* * *}$ & $0.21^{* * *}$ & $-0.08^{* * * *}$ & 0.003 & $-0.04 * * *$ & $-0.10^{* * *}$ & $0.08 * * *$ & $-0.07 * * *$ & $-0.03 * * *$ & $-0.05^{* * * *}$ & $-0.15 * * *$ & $-0.06^{* * * *}$ & $-0.21 * * *$ & -0.004 & 1.00 & & & & \\
\hline 21 & -0.004 & $-0.06 * * *$ & $0.12^{* * *}$ & $0.15^{* * *}$ & -0.01 & $0.08^{* * *}$ & $0.02^{* *}$ & $0.08^{* * *}$ & $0.10^{* * *}$ & $-0.13^{* * *}$ & $-0.05 * * *$ & $-0.22 * * *$ & $-0.03 * * *$ & $-0.02^{*}$ & $-0.02^{* * *}$ & $-0.05 * * *$ & $-0.02^{* * *}$ & $-0.04 * * *$ & $-0.02^{* *}$ & 0.02 & 1.00 & & & \\
\hline 22 & $0.06^{* * *}$ & $0.17 * * *$ & $-0.10^{* * * *}$ & $-0.16^{* * *}$ & 0.01 & $-0.08^{* * * *}$ & $-0.06^{* * *}$ & $0.02^{*}$ & $-0.02^{* *}$ & $0.08^{* * *}$ & $-0.05 * * *$ & $-0.10^{* * * *}$ & $-0.03^{* * *}$ & $-0.02^{* *}$ & $-0.03 * *$ & $0.13^{* * *}$ & $-0.03^{* *}$ & $-0.09 * * *$ & $-0.03 * * *$ & $-0.08^{* * * *}$ & $-0.03^{* * *}$ & 1.00 & & \\
\hline 23 & $0.07 * * *$ & $-0.17^{* * *}$ & $-0.03^{* *}$ & $-0.03^{* * *}$ & 0.01 & $0.05^{* * *}$ & $0.08 * * *$ & $0.04^{* * *}$ & 0.001 & $-0.07 * * *$ & $-0.03 * * *$ & $-0.14^{* * *}$ & $-0.02 * *$ & -0.01 & -0.01 & $-0.03 * * *$ & -0.01 & $-0.05 * * *$ & -0.02 & $-0.03^{* * * *}$ & $-0.02^{*}$ & -0.01 & 1.00 & \\
\hline 24 & $0.02 * *$ & $0.08 * * *$ & $0.04 * * *$ & $-0.09 * * *$ & 0.001 & $0.08 * * *$ & $0.05 * * *$ & -0.01 & $-0.04 * * *$ & $0.07 * * *$ & $-0.03 * * *$ & $-0.03^{* * *}$ & $-0.02^{* * *}$ & -0.01 & -0.001 & $-0.02^{* * *}$ & -0.01 & $-0.05 * * *$ & -0.02 & $-0.05^{* * * *}$ & $-0.02^{*}$ & $0.06^{* * *}$ & -0.01 & 1.00 \\
\hline 25 & $-0.07^{* * *}$ & $-0.05 * * *$ & 0.01 & 0.01 & -0.0003 & -0.01 & 0.0004 & $-0.02^{* *}$ & $0.02^{*}$ & $-0.05^{* * *}$ & $-0.03 * *$ & $-0.11 * * *$ & $-0.02^{* * *}$ & -0.01 & -0.02 & $-0.04 * * *$ & $0.02^{*}$ & $-0.04 * * *$ & 0.01 & $-0.03^{* * *}$ & $0.02^{*}$ & $-0.02^{* * *}$ & -0.01 & -0.01 \\
\hline
\end{tabular}

Notes. a. $N=10,094$. b. Significance levels: * $p<0.10$, ** $p<0.05, * * * p<0.01$. c. 1. Japanese parent MNE employment (ln); 2. Overseas subsidiary employment (ln); 3. Host country GDP (In); 4. Ratio of Japanese GDP by industry (\%); 5. Unemployment rate in Japan (\%); 6. Distance between Japan and host countries (In); 7. Rule of law; 8. Parent MNE local networks (In); 9. Parent MNE R\&D ratio (\%); 10. Overseas subsidiary revenue (In); 11. MD1. Building international Building international networks of production; 19. MD9. Natural resources, materials; 20. MD10. Information gathering, royalty revenue; 21. MD11. R\&D; 22. MD12. Tax breaks for investment; 23. MD13. Financing, currency hedging; 24. MD14. Trade conflict; 25. MD15. Building new busines. 
Table 3. 3SLS regression results: Full sample

\begin{tabular}{|c|c|c|c|c|c|c|}
\hline & \multicolumn{2}{|c|}{ Model 1} & \multicolumn{2}{|c|}{ Model 2} & \multicolumn{2}{|c|}{ Model 3} \\
\hline & $\begin{array}{r}\text { Parent MNE } \\
\text { employment } \\
\text { equation }\end{array}$ & $\begin{array}{c}\text { Subsidiary } \\
\text { employment } \\
\text { equation. }\end{array}$ & $\begin{array}{r}\text { Parent MNE } \\
\text { employment } \\
\text { equation }\end{array}$ & $\begin{array}{r}\text { Subsidiary } \\
\text { employment } \\
\text { equation } \\
\end{array}$ & $\begin{array}{r}\text { Parent MNE } \\
\text { employment } \\
\text { equation }\end{array}$ & $\begin{array}{r}\text { Subsidiary } \\
\text { employment } \\
\text { equation }\end{array}$ \\
\hline Overseas subsidiary employment $(\ln )$ & $0.535 * * *[0.013]$ & & $0.539 * * *[0.013]$ & & $0.538 * * *[0.013]$ & \\
\hline Parent MNE employment (ln) & & $-0.525[0.609]$ & & $-0.389[0.660]$ & & $-0.452[0.665]$ \\
\hline Host country GDP $(\ln )$ & $-0.222 * * *[0.014]$ & $-0.198[0.157]$ & $-0.234 * * *[0.014]$ & $-0.151[0.174]$ & $-0.235 * * *[0.014]$ & $-0.166[0.175]$ \\
\hline Ratio of Japanese GDP by industry (\%) & $0.023[0.019]$ & $-0.039^{* *}[0.020]$ & $0.033 *[0.018]$ & $-0.037 *[0.019]$ & $0.045^{* * *}[0.019]$ & $-0.055^{* * *}[0.020]$ \\
\hline Unemployment rate in Japan (\%) & $2.279 * * *[0.144]$ & $1.755[1.604]$ & $2.248 * * *[0.143]$ & $1.439[1.755]$ & $2.233 * * *[0.143]$ & $1.663[1.768]$ \\
\hline Distance between Japan and host countries (ln) & $0.0004[0.002]$ & $0.006^{* *}[0.003]$ & $0.001[0.002]$ & $0.006^{* *}[0.003]$ & $0.001[0.002]$ & $0.006^{* *}[0.003]$ \\
\hline Host country rule of law & $0.277 * * *[0.023]$ & $-0.751 * * *[0.064]$ & $0.253^{* * *}[0.023]$ & $-0.692 * * *[0.069]$ & $0.253 * * *[0.023]$ & $-0.693 * * *[0.068]$ \\
\hline Parent MNE local networks (ln) & $0.798 * * *[0.020]$ & $0.544[0.519]$ & $0.813 * * *[0.019]$ & $0.406[0.564]$ & $0.817 * * *[0.020]$ & $0.462[0.571]$ \\
\hline Parent MNE R\&D ratio (\%) & $-0.957 * * *[0.431]$ & & $-0.767 *[0.431]$ & & $-0.806 *[0.431]$ & \\
\hline Overseas subsidiary revenue $(\ln )$ & & $0.619 * * *[0.158]$ & & $0.571 * * *[0.168]$ & & $0.587 * * *[0.169]$ \\
\hline \multicolumn{7}{|l|}{ I. Market-seeking FDI (Domestic market expansion) } \\
\hline MD1. Building international networks of distribution & & & $-0.005[0.049]$ & $-0.510 * * *[0.159]$ & $0.181[0.154]$ & $-0.804 * * *[0.209]$ \\
\hline MD2. Market access & & & $0.146 * * *[0.034]$ & $0.091[0.111]$ & $0.268 * * *[0.048]$ & $-0.103[0.124]$ \\
\hline MD3. Export to other countries & & & $0.059[0.064]$ & $-0.094[0.062]$ & $0.246^{* *}[0.107]$ & $0.320[0.247]$ \\
\hline MD4. Controls business of the area & & & $0.230^{* *}[0.104]$ & $-0.664 * * *[0.123]$ & $0.542 * * *[0.206]$ & $-1.762 * * *[0.301]$ \\
\hline \multicolumn{7}{|l|}{ II. Market-seeking FDI (Domestic demand decline) } \\
\hline MD5. Alliance with customers in Japan & & & $-0.449 * * *[0.084]$ & $-0.119[0.295]$ & $-0.449 * * *[0.084]$ & $-0.130[0.293]$ \\
\hline $\begin{array}{l}\text { MD1. Building international networks of distribution } \times \\
\text { Ratio of Japanese GDP by industry }(\%)\end{array}$ & & & & & $-0.017[0.011]$ & $0.025^{* *}[0.011]$ \\
\hline $\begin{array}{l}\text { MD2. Market access } \times \\
\text { Ratio of Japanese GDP by industry (\%) }\end{array}$ & & & & & $-0.016 * * *[0.004]$ & $0.025 * * *[0.004]$ \\
\hline $\begin{array}{l}\text { MD3. Export to other countries } \times \\
\text { Ratio of Japanese GDP by industry (\%) }\end{array}$ & & & & & $-0.023 * *[0.010]$ & $-0.045 *[0.027]$ \\
\hline $\begin{array}{l}\text { MD4. Controls business of the area } \times \\
\text { Ratio of Japanese GDP by industry (\%) }\end{array}$ & & & & & $-0.029 *[0.016]$ & $0.098 * * *[0.020]$ \\
\hline
\end{tabular}


III. Labor-seeking FDI

MD6. Labor intensity

MD7. Exports to Japan

IV. Natural-resource-seeking FDI

MD9. Natural resources, materials

\section{Strategic-asset-seeking FDI}

MD10. Information gathering, royalty revenue

MD11. R\&D

VI. Other FDI motivations

MD12. Tax breaks for investment

MD13. Financing, currency hedging

MD14. Trade conflict

MD15. Building new business

Year fixed effects

Regional fixed effects

Industry fixed effects

$\mathrm{R}^{2}$

\section{$\chi^{2}$}

MD8. Building international networks of production

\begin{tabular}{|c|c|c|c|c|c|}
\hline & & $-0.160 * * *[0.046]$ & $0.353 * * *[0.047]$ & $-0.145 * * *[0.046]$ & $0.342 * * *[0.049]$ \\
\hline & & $-0.048[0.089]$ & $0.136[0.088]$ & $-0.026[0.089]$ & $0.091[0.090]$ \\
\hline & & $-0.006[0.040]$ & $0.171 * * *[0.062]$ & $0.025[0.041]$ & $0.148 * *[0.070]$ \\
\hline & & $0.116[0.090]$ & $-0.653 * * *[0.157]$ & $0.124[0.089]$ & $-0.679 * * *[0.159]$ \\
\hline & & $0.314 * * *[0.033]$ & $-0.252 * *[0.103]$ & $0.311 * * *[0.033]$ & $-0.250 * *[0.100]$ \\
\hline & & $0.121[0.080]$ & $0.092[0.116]$ & $0.070[0.081]$ & $0.174[0.114]$ \\
\hline & & $-0.092[0.069]$ & $0.335 * * *[0.083]$ & $-0.067[0.069]$ & $0.317 * * *[0.088]$ \\
\hline & & $0.439 * *[0.178]$ & $-0.755 * * *[0.174]$ & $0.442 * *[0.178]$ & $-0.772 * * *[0.178]$ \\
\hline & & $0.0005[0.113]$ & $0.139[0.119]$ & $0.026[0.113]$ & $0.113[0.124]$ \\
\hline & & $-0.202 * *[0.097]$ & $-0.345[0.234]$ & $-0.222 * *[0.098]$ & $-0.331[0.237]$ \\
\hline Yes & Yes & Yes & Yes & Yes & Yes \\
\hline Yes & Yes & Yes & Yes & Yes & Yes \\
\hline Yes & Yes & Yes & Yes & Yes & Yes \\
\hline 0.330 & 0.495 & 0.341 & 0.579 & 0.343 & 0.556 \\
\hline $6,342.3^{* * *}$ & $114,899.3 * * *$ & $573,737.5 * * *$ & $138,303.2 * * *$ & $575,168.0^{* * *}$ & $131,176.7 * * *$ \\
\hline
\end{tabular}

\begin{tabular}{|c|c|c|c|c|c|}
\hline & & $-0.160 * * *[0.046]$ & $0.353 * * *[0.047]$ & $-0.145 * * *[0.046]$ & $0.342 * * *[0.049]$ \\
\hline & & $-0.048[0.089]$ & $0.136[0.088]$ & $-0.026[0.089]$ & $0.091[0.090]$ \\
\hline & & $-0.006[0.040]$ & $0.171 * * *[0.062]$ & $0.025[0.041]$ & $0.148 * *[0.070]$ \\
\hline & & $0.116[0.090]$ & $-0.653 * * *[0.157]$ & $0.124[0.089]$ & $-0.679 * * *[0.159]$ \\
\hline & & $0.314 * * *[0.033]$ & $-0.252 * *[0.103]$ & $0.311 * * *[0.033]$ & $-0.250 * *[0.100]$ \\
\hline & & $0.121[0.080]$ & $0.092[0.116]$ & $0.070[0.081]$ & $0.174[0.114]$ \\
\hline & & $-0.092[0.069]$ & $0.335 * * *[0.083]$ & $-0.067[0.069]$ & $0.317 * * *[0.088]$ \\
\hline & & $0.439 * *[0.178]$ & $-0.755 * * *[0.174]$ & $0.442 * *[0.178]$ & $-0.772 * * *[0.178]$ \\
\hline & & $0.0005[0.113]$ & $0.139[0.119]$ & $0.026[0.113]$ & $0.113[0.124]$ \\
\hline & & $-0.202 * *[0.097]$ & $-0.345[0.234]$ & $-0.222 * *[0.098]$ & $-0.331[0.237]$ \\
\hline Yes & Yes & Yes & Yes & Yes & Yes \\
\hline Yes & Yes & Yes & Yes & Yes & Yes \\
\hline Yes & Yes & Yes & Yes & Yes & Yes \\
\hline 0.330 & 0.495 & 0.341 & 0.579 & 0.343 & 0.556 \\
\hline $6,342.3^{* * *}$ & $114,899.3 * * *$ & $573,737.5 * * *$ & $138,303.2 * * *$ & $575,168.0^{* * *}$ & $131,176.7 * * *$ \\
\hline
\end{tabular}

Notes. a $N=10,094$ b. Significance levels: $* p<0.10 * * p<0.05 * * * p<0.01$. c. Numbers in [ ] are standardized errors. d. Year fixed effects: 1996-2010. e. Regional fixed effects: Asia; Middle East; Europe; North America; Latin America; Africa; Oceania. f. Industry fixed effects: Agriculture, forestry, and fishing; Mining; Food products and beverages; Textiles; Pulp, paper, and paper products; Chemicals; Petroleum and coal products; Non-metallic mineral products; Iron and steel; Fabricated metal products; Machinery; Electrical machinery, equipment, and supplies; Transport equipment; Precision instruments; Manufacturing others; Construction; Electricity, gas, and water supply; Wholesale and retail trade; Finance and insurance; Real estate; Transport and communications; Service activities. 
Table 4. 3SLS regression results: Subsample with ownership $\geq 50 \%$

\begin{tabular}{|c|c|c|c|c|c|c|}
\hline & \multicolumn{2}{|c|}{ Model 1} & \multicolumn{2}{|c|}{ Model 2} & \multicolumn{2}{|c|}{ Model 3} \\
\hline & $\begin{array}{r}\text { Parent MNE } \\
\text { employment } \\
\text { equation }\end{array}$ & $\begin{array}{r}\text { Subsidiary } \\
\text { employment } \\
\text { equation } \\
\end{array}$ & $\begin{array}{r}\text { Parent MNE } \\
\text { employment } \\
\text { equation }\end{array}$ & $\begin{array}{r}\text { Subsidiary } \\
\text { employment } \\
\text { equation }\end{array}$ & $\begin{array}{r}\text { Parent MNE } \\
\text { employment } \\
\text { equation }\end{array}$ & $\begin{array}{r}\text { Subsidiary } \\
\text { employment } \\
\text { equation } \\
\end{array}$ \\
\hline Overseas subsidiary employment $(\ln )$ & $0.555^{* * *}[0.015]$ & & $0.562 * * *[0.016]$ & & $0.558 * * *[0.016]$ & \\
\hline Parent MNE employment $(\ln )$ & & $-0.406[0.348]$ & & $-0.210[0.306]$ & & $-0.207[0.297]$ \\
\hline Host country GDP $(\ln )$ & $-0.191 * * *[0.016]$ & $-0.208^{* *}[0.089]$ & $-0.204 * * *[0.016]$ & $-0.148 *[0.080]$ & $-0.205^{* * *}[0.016]$ & $-0.147[0.078]^{*}$ \\
\hline Ratio of Japanese GDP by industry (\%) & $0.034 *[0.021]$ & $-0.028[0.021]$ & $0.046^{* *}[0.021]$ & $-0.034 *[0.019]$ & $0.063^{* * *}[0.021]$ & $-0.050 * *[0.020]$ \\
\hline Unemployment rate in Japan (\%) & $1.919^{* * *}[0.189]$ & $1.536 *[0.876]$ & $1.950^{* * *}[0.188]$ & $1.396 *[0.758]$ & $1.926^{* * *}[0.187]$ & $1.049[0.737]$ \\
\hline Distance between Japan and host countries (ln) & $0.001[0.002]$ & $0.003[0.002]$ & $0.001[0.002]$ & $0.002[0.002]$ & $0.002[0.002]$ & $0.002[0.002]$ \\
\hline Host country rule of law & $0.297 * * *[0.026]$ & $-0.796^{* * *}[0.048]$ & $0.256^{* * *}[0.027]$ & $-0.720 * * *[0.046]$ & $0.254 * * *[0.027]$ & $-0.713 * * *[0.044]$ \\
\hline Parent MNE local networks (ln) & $0.784 * * *[0.022]$ & $0.513 *[0.305]$ & $0.797 * * *[0.022]$ & $0.313[0.267]$ & $0.804 * * *[0.022]$ & $0.311[0.261]$ \\
\hline Parent MNE R\&D ratio (\%) & $-1.550 * * *[0.448]$ & & $-1.442 * * *[0.446]$ & & $-1.479 * * *[0.446]$ & \\
\hline Overseas subsidiary revenue $(\ln )$ & & $0.560 * * *[0.089]$ & & $0.496^{* * *}[0.076]$ & & $0.495 * * *[0.074]$ \\
\hline \multicolumn{7}{|l|}{ I. Market-seeking FDI (Domestic market expansion) } \\
\hline MD1. Building international networks of distribution & & & $0.023[0.052]$ & $-0.450 * * *[0.077]$ & $0.248[0.169]$ & $-0.697 * * *[0.155]$ \\
\hline MD2. Market access & & & $0.168 * * *[0.037]$ & $0.094[0.069]$ & $0.357 * * *[0.054]$ & $-0.079[0.096]$ \\
\hline MD3. Export to other countries & & & $0.195^{* * *}[0.069]$ & $-0.143 * *[0.069]$ & $0.561^{* * *}[0.121]$ & $0.110[0.196]$ \\
\hline MD4. Controls business of the area & & & $0.397 * * *[0.110]$ & $-0.532 * * *[0.100]$ & $1.154 * * *[0.236]$ & $-1.690 * * *[0.214]$ \\
\hline \multicolumn{7}{|l|}{ II. Market-seeking FDI (Domestic demand decline) } \\
\hline MD5. Alliance with customers in Japan & & & $-0.507 * * *[0.090]$ & $-0.017[0.165]$ & $-0.500 * * *[0.090]$ & $-0.011[0.159]$ \\
\hline $\begin{array}{l}\text { MD1. Building international networks of distribution } \times \\
\text { Ratio of Japanese GDP by industry }(\%)\end{array}$ & & & & & $-0.020 *[0.012]$ & $0.022 * *[0.011]$ \\
\hline $\begin{array}{l}\text { MD2. Market access } \times \\
\text { Ratio of Japanese GDP by industry (\%) }\end{array}$ & & & & & $-0.023 * * *[0.005]$ & $0.020 * * *[0.005]$ \\
\hline $\begin{array}{l}\text { MD3. Export to other countries } \times \\
\text { Ratio of Japanese GDP by industry (\%) }\end{array}$ & & & & & $-0.042 * * *[0.011]$ & $-0.026[0.028]$ \\
\hline $\begin{array}{l}\text { MD4. Controls business of the area } \times \\
\text { Ratio of Japanese GDP by industry (\%) }\end{array}$ & & & & & $-0.065 * * *[0.017]$ & $0.096^{* * *}[0.015]$ \\
\hline
\end{tabular}




\section{Labor-seeking FDI}

MD6. Labor intensity

MD7. Exports to Japan

MD8. Building international networks of production

\section{Natural-resource-seeking FDI}

MD9. Natural resources, materials

\section{Strategic-asset-seeking FDI}

MD10. Information gathering, royalty revenue

MD11. R\&D

\section{Other FDI motivations}

MD12. Tax breaks for investment

MD13. Financing, currency hedging

MD14. Trade conflict

MD15. Building new business

Year fixed effects

Regional fixed effects

Industry fixed effects

$\mathrm{R}^{2}$

$\chi^{2}$

$$
\begin{array}{r}
-0.156^{* * *}[0.051] \\
-0.003[0.094] \\
-0.043[0.045]
\end{array}
$$

$0.443 * * *[0.050]$

$0.168 *[0.087]$

$0.175 * * *[0.043]$

$0.330 * * *[0.097]$

$-0731 * * *[0.089]$

$0.398 * * *[0.035]$

$0.166 * *[0.084]$

$-0.318 * * *[0.068]$

$0.193 *[0.101]$

$.392 * * *[0.035]$

$0.102[0.085]$

$-0.322 * * *[0.065]$

-0.067 [0.079]

$0.768 * * *[0.201]$

$0.469 * * *[0.089]$

$-0.844 * * *[0.193]$

-0.008 [0.117]

$0.163[0.106]$

-0.110 [0.104]

$-0.243 * *[0.114]$

Yes

Yes

Yes

0.341

0.535

$105,124.3 * * *$

$\begin{array}{cc}-0.024[0.079] & 0.439 * * *[0.092] \\ 0.777 * * *[0.201] & -0.869^{* * *}[0.191] \\ 0.041[0.117] & 0.129[0.108] \\ -0.135[0.103] & -0.218^{*}[0.115] \\ \text { Yes } & \text { Yes } \\ \text { Yes } & \text { Yes } \\ \text { Yes } & \text { Yes } \\ 0.346 & 0.636 \\ 489,212.8 * * * & 134,934.8 * * *\end{array}$

Notes. a. $N=8,712$. b. Significance levels: $* p<0.10, * * p<0.05$, *** $p<0.01$. c. Numbers in [ ] are standardized errors. d. Year fixed effects: 1996-2010. e. Regional fixed effects: Asia; Middle East; Europe; North America; Latin America; Africa; Oceania. f. Industry fixed effects: Agriculture, forestry, and fishing; Mining; Food products and beverages; Textiles; Pulp, paper, and paper products; Chemicals; Petroleum and coal products; Non-metallic mineral products; Iron and steel; Fabricated metal products; Machinery; Electrical machinery, equipment, and supplies; Transport equipment; Precision instruments; Manufacturing others; Construction; Electricity, gas, and water supply; Wholesale and retail trade; Finance and insurance; Real estate; Transport and communications; Service activities. 
Table 5. Summary of Empirical Results and Hypothesis Testing

\begin{tabular}{|c|c|c|}
\hline Hypothesis & Outbound FDI Motivation & Empirical Evidence \\
\hline H1 & $\begin{array}{l}\text { - Market-seeking FDI (+) } \\
\text { - Scale expansion } \\
\text { - Scope expansion }\end{array}$ & Partially Supported \\
\hline $\mathrm{H} 2$ & $\begin{array}{l}\text { - } \quad \text { Market-seeking FDI (-) } \\
\text { - Associated with domestic demand decline }\end{array}$ & Supported \\
\hline H3 & $\begin{array}{l}\text { - Labor-seeking FDI (-) } \\
\text { - Replacement of inefficient domestic labor forces }\end{array}$ & Partially Supported \\
\hline $\mathrm{H} 4$ & $\begin{array}{l}\text { - Natural-resource-seeking FDI }(+) \\
\text { - Access to scarce and immobile foreign endowment of natural } \\
\text { resources }\end{array}$ & Partially Supported \\
\hline H5 & $\begin{array}{l}\text { - Strategic-asset-seeking FDI (+) } \\
\text { - Home-base-exploiting R\&D activities } \\
\text { - Home-base-augmenting R\&D activities }\end{array}$ & Partially Supported \\
\hline
\end{tabular}


Table 6. Robustness Test Results (Ownership $\geq 50 \%$, Parent MNE Equation)

\begin{tabular}{|c|c|c|c|c|c|c|}
\hline & $\begin{array}{l}\text { Parent MNE } \\
\text { employment } \\
\text { at }(t+1)\end{array}$ & $\begin{array}{l}\text { Parent MNE } \\
\text { employment } \\
\quad \text { at }(t+2)\end{array}$ & $\begin{array}{l}\text { Parent MNE } \\
\text { employment } \\
\text { at }(t+3)\end{array}$ & $\begin{array}{l}\text { Parent MNE } \\
\text { with one } \\
\text { subsidiary }\end{array}$ & $\begin{array}{c}\text { Subsidiary with } \\
\text { one FDI } \\
\text { motivation }\end{array}$ & System GMM \\
\hline Overseas subsidiary employment $(\ln )$ & $0.757 * * *[0.017]$ & $0.746^{* * *}[0.018]$ & $0.752 * * *[0.020]$ & $0.569^{* * *}[0.021]$ & $0.577 * * *[0.021]$ & $0.148 * * *[0.019]$ \\
\hline Host country GDP (ln) & $-0.149 * * *[0.018]$ & $-0.129 * * *[0.019]$ & $-0.102 * * *[0.021]$ & $-0.141 * * *[0.020]$ & $-0.297 * * *[0.023]$ & $-0.030[0.020]$ \\
\hline Ratio of Japanese GDP by industry (\%) & $0.062 * *[0.024]$ & $0.075^{* * *}[0.026]$ & $0.080^{* * *}[0.029]$ & $0.137 * * *[0.029]$ & $0.050 *[0.029]$ & $0.014 * *[0.006]$ \\
\hline Unemployment rate in Japan (\%) & $1.370 * * *[0.225]$ & $1.289 * * *[0.277]$ & $1.180 * * *[0.280]$ & $1.556^{* * *}[0.201]$ & $2.272 * * *[0.268]$ & $-0.582[0.377]$ \\
\hline Distance between Japan and host countries (ln) & $0.001[0.002]$ & $0.001[0.002]$ & $0.001[0.002]$ & $0.00003[0.002]$ & $-0.007 * *[0.003]$ & $0.030 * * *[0.008]$ \\
\hline Host country rule of law & $0.377 * * *[0.030]$ & $0.374 * * *[0.032]$ & $0.393 * * *[0.034]$ & $0.184 * * *[0.035]$ & $0.156^{* * *}[0.039]$ & $0.078 * * *[0.022]$ \\
\hline Parent MNE local networks (ln) & $0.708 * * *[0.025]$ & $0.709 * * *[0.026]$ & $0.710 * * *[0.028]$ & & $0.908 * * *[0.031]$ & $0.441 * * *[0.043]$ \\
\hline Parent MNE R\&D ratio (\%) & $-0.406[0.425]$ & $-0.056[0.467]$ & $0.101[0.515]$ & $-2.726 * * *[0.563]$ & $-2.583 * * *[0.712]$ & $-2.537 * * *[0.435]$ \\
\hline \multicolumn{7}{|l|}{ I. Market-seeking FDI (Domestic market expansion) } \\
\hline MD1. Building international networks of distribution & $0.340 *[0.194]$ & $0.415 * *[0.206]$ & $0.400 *[0.221]$ & $0.411 *[0.231]$ & $1.572 * * *[0.461]$ & $0.063[0.191]$ \\
\hline MD2. Market access & $0.345^{* * *}[0.062]$ & $0.341 * * *[0.065]$ & $0.344 * * *[0.069]$ & $0.555 * * *[0.081]$ & $0.394 * * *[0.139]$ & $-0.304[0.197]$ \\
\hline MD3. Export to other countries & $0.521 * * *[0.138]$ & $0.578 * * *[0.144]$ & $0.540 * * *[0.154]$ & $1.001 * * *[0.173]$ & $-0.892[0.665]$ & $0.657 * * *[0.210]$ \\
\hline MD4. Controls business of the area & $1.469 * * *[0.266]$ & $1.472 * * *[0.279]$ & $1.336^{* * *}[0.303]$ & $1.200 * * *[0.333]$ & $1.229 * * *[0.439]$ & $0.347[0.341]$ \\
\hline \multicolumn{7}{|l|}{ II. Market-seeking FDI (Domestic demand decline) } \\
\hline MD5. Alliance with customers in Japan & $-0.504 * * *[0.105]$ & $-0.493 * * *[0.113]$ & $-0.475^{* * *}[0.122]$ & $-0.430 * * *[0.131]$ & $-0.652 * * *[0.199]$ & $-0.991[0.780]$ \\
\hline $\begin{array}{l}\text { MD1. Building international networks of distribution } \times \\
\text { Ratio of Japanese GDP by industry }(\%)\end{array}$ & $-0.018[0.014]$ & $-0.022[0.015]$ & $-0.022[0.016]$ & $-0.029 *[0.016]$ & $-0.086 * * *[0.032]$ & $-0.044 * * *[0.008]$ \\
\hline $\begin{array}{l}\text { MD2. Market access } \times \\
\text { Ratio of Japanese GDP by industry (\%) }\end{array}$ & $-0.024 * * *[0.005]$ & $-0.023 * * *[0.006]$ & $-0.024 * * *[0.006]$ & $-0.039 * * *[0.007]$ & $-0.018 * *[0.009]$ & $-0.013 *[0.007]$ \\
\hline $\begin{array}{l}\text { MD3. Export to other countries } \times \\
\text { Ratio of Japanese GDP by industry (\%) }\end{array}$ & $-0.036 * * *[0.012]$ & $-0.043 * * *[0.013]$ & $-0.043 * * *[0.014]$ & $-0.075 * * *[0.016]$ & $-0.044[0.052]$ & $-0.064 * * *[0.013]$ \\
\hline $\begin{array}{l}\text { MD4. Controls business of the area } \times \\
\text { Ratio of Japanese GDP by industry ( } \%)\end{array}$ & $-0.082 * * *[0.019]$ & $-0.082 * * *[0.020]$ & $-0.074 * * *[0.022]$ & $-0.039^{\Psi}[0.024]$ & $-0.101 * * *[0.037]$ & $-0.032 * *[0.014]$ \\
\hline \multicolumn{7}{|l|}{ III. Labor-seeking FDI } \\
\hline MD6. Labor intensity & $-0.262 * * *[0.058]$ & $-0.270 * * *[0.060]$ & $-0.300 * * *[0.063]$ & $0.170 * *[0.076]$ & $-0.009[0.159]$ & $-0.868 * * *[0.308]$ \\
\hline MD7. Exports to Japan & $0.064[0.104]$ & $0.104[0.106]$ & $0.099[0.111]$ & $0.282 *[0.168]$ & $0.339[0.251]$ & $0.104[0.550]$ \\
\hline
\end{tabular}


MD8. Building international networks of production

IV. Natural-resource-seeking FDI

MD9. Natural resources, materials

\section{Strategic-asset-seeking FDI}

MD10. Information gathering, royalty revenue

MD11. R\&D

\section{Other FDI motivations}

MD12. Tax breaks for investment

MD13. Financing, currency hedging

MD14. Trade conflict

MD15. Building new business

Year fixed effects

Regional fixed effects

Industry fixed effects

Number of observations

$\mathrm{R}^{2}$

$\chi^{2}$

Number of instruments

Hansen's J test ( $p$-value)

Difference-in-Hansen test ( $p$-value)

$\operatorname{AR}(1)$ test in differences ( $p$-value)

$\operatorname{AR}(2)$ test in differences ( $p$-value)

\begin{tabular}{|c|c|c|c|c|c|}
\hline$-0.022[0.051]$ & $-0.008[0.054]$ & $-0.010[0.057]$ & $0.098[0.064]$ & $-0.014[0.134]$ & $-0.880 * * *[0.247]$ \\
\hline $0.435 * * *[0.111]$ & $0.434 * * *[0.116]$ & $0.298 * *[0.124]$ & $0.088[0.130]$ & $0.675^{* * *}[0.205]$ & $2.119 * *[1.034]$ \\
\hline $0.471 * * *[0.040]$ & $0.465 * * *[0.041]$ & $0.443 * * *[0.043]$ & $0.399 * * *[0.045]$ & $0.804 * * *[0.159]$ & $-0.079[0.291]$ \\
\hline $0.158^{\Psi}[0.098]$ & $0.186^{*}[0.102]$ & $0.189 *[0.110]$ & $0.286 * *[0.129]$ & $0.438 * * *[0.167]$ & $-0.519[0.332]$ \\
\hline$-0.205 * *[0.089]$ & $-0.212 * *[0.093]$ & $-0.228 * *[0.099]$ & $0.039[0.110]$ & $0.733 * * *[0.265]$ & $3.046 * * *[0.847]$ \\
\hline $1.013 * * *[0.222]$ & $0.918 * * *[0.235]$ & $0.940 * * *[0.250]$ & $0.548 *[0.329]$ & $1.168 * * *[0.341]$ & $1.603 * *[0.634]$ \\
\hline$-0.097[0.131]$ & $-0.114[0.133]$ & $-0.220[0.142]$ & $0.379 * * *[0.144]$ & $-0.567 *[0.329]$ & $2.366^{* *}[1.114]$ \\
\hline$-0.066[0.123]$ & $-0.094[0.135]$ & $-0.217[0.153]$ & $-0.124[0.135]$ & $-0.475 * *[0.194]$ & $0.328[0.818]$ \\
\hline Yes & Yes & Yes & Yes & Yes & Yes \\
\hline Yes & Yes & Yes & Yes & Yes & Yes \\
\hline Yes & Yes & Yes & Yes & Yes & Yes \\
\hline 7,827 & 7,045 & 6,252 & 5,087 & 4,391 & 15,899 \\
\hline 0.243 & 0.248 & 0.254 & 0.246 & 0.387 & \\
\hline \multirow[t]{6}{*}{$389,128.6^{* * *}$} & $361,581.2 * * *$ & $325,123.4 * * *$ & $258,439.9 * * *$ & $245,135.0 * * *$ & $26.88 * * *$ \\
\hline & & & & & 441 \\
\hline & & & & & 0.316 \\
\hline & & & & & 0.975 \\
\hline & & & & & 0.019 \\
\hline & & & & & 0.243 \\
\hline
\end{tabular}

Notes. a. Significance levels: $* p<0.10 * * p<0.05, * * * p<0.01$. b. Numbers in [ ] are standardized errors. c. Year fixed effects: 1996-2010. d. Regional fixed effects: Asia; Middle East; Europe; North America; Latin America; Africa; Oceania. e. Industry fixed effects: Agriculture, forestry, and fishing; Mining; Food products and beverages; Textiles; Pulp, paper, and paper products; Chemicals; Petroleum and coal products; Non-metallic mineral products; Iron and steel; Fabricated metal products; Machinery; Electrical machinery, equipment, and supplies; Transport equipment; Precision instruments; Manufacturing others; Construction; Electricity, gas, and water supply; Wholesale and retail trade; Finance and insurance; Real estate; Transport and communications; Service activities. 